\title{
Biodiversity and agri-environmental indicators-general scopes and skills with special reference to the habitat level
}

\author{
Wolfgang Büchs* \\ Federal Biological Research Centre for Agriculture and Forestry, Institute for Plant Protection in Field Crops and Grassland, \\ Messeweg 11/12, DE-38104 Braunschweig, Germany
}

\begin{abstract}
This synoptic review has the intention to summarise and highlight results in respect to the area "biodiversity and habitat" considering the current "state of the art" with regard the development of biotic indicator approaches that refer to the fauna of agro-ecosystems.

Most political statements (e.g. "Convention of Biodiversity Development": Agenda 21, Convention of Rio 1992) as well as existing approaches regarding the development of biotic agri-environmental indicators focus mainly and almost exclusively on "biodiversity", the enhancement of which is the overall target for the development of agricultural landscapes towards sustainability. In this regard the understanding of the term "biodiversity" is rather different: it is largely interpreted as species richness, only occasionally as the richness of varieties, cultivars or genetical expressions (e.g. microorganisms).

A survey on the understanding of biotic indicators is presented including aspects of nomenclature, categorisation and definitions as well as preconditions and rules for their use. Requirements for different taxa (mostly invertebrates) to act as biotic indicators are summarised and several attempts to use animals on the population and/or community level as biotic indicators for biodiversity or other goals in agro-ecosystems are discussed critically as well as their replacement by surrogate indicators. Regarding the sensitivity of indicators it will be highlighted that it is necessary to evaluate and to compare cultivation intensities, that are rather similar (e.g. gradual differences in conventional managed farms and landscapes) as well as those displaying much larger differences (e.g. organic farming versus conventional farming), because conventional farms currently cover nearly $90 \%$ of the agriculturally used area in Europe. Other fundamental problems regarding the development of biotic indicators as baselines, sample size, frequency of surveys, mutual neutralisation of indicators, double assessments, selection of taxa, etc. are addressed. Finally an assessment of the practicality, the power of indication statements and the remaining work required to validate indicators will be provided for discussion, as well as suggestions for a simplification of indicator systems in order to minimise the input needed for data recording.
\end{abstract}

(C) 2003 Elsevier B.V. All rights reserved.

Keywords: Biodiversity assessment; Biotic indicator; Cultivated area; Agriculture; Animals

\section{Introduction-“biodiversity": a term made for confusion?}

Already in the 1970 s in central Europe various societies for nature protection (e.g. World Wildlife

* Tel.: +49-531-299-4506; fax: +49-531-299-3008.

E-mail address: w.buechs@bba.de (W. Büchs).
Fund (WWF), Bund für Umwelt und Natuschutz Deutschland (BUND), Naturschutzbund (NABU)) as well as departments for environmental protection in some federal states used the slogan "species richness means quality of life" to stand for the conservation and protection of the diversity of life forms (species, varieties, genetical resources), especially in rural landscapes. The term "biodiversity", however, became 
more public only after the signing of the "Convention for Biodiversity" (e.g. UNEP-Conference Nairobi, Kenya, May 1992; "Earth Summit" Rio de Janeiro, Brazil, June 1992) by 168 countries.

Today "biodiversity" is a term familiar to many: hardly any research programme with an ecological intention is able to manage without using the term "biodiversity". Similar to the term "ecology" which was coined more than 30 years ago, the term "biodiversity" has also been picked up by several groups of society in central Europe with completely different goals. Examples are as follows:

- Call for a year of "International Biodiversity Observation 2001-2002", an initiative by Diversitas, an international consortium of environmental protection.

- Founding of an international journal "Biodiversity and Conservation" by the Ulmer-Verlag, Stuttgart, Germany.

- Call for Research \& Development proposals by the European Commission within the fifth framework-programme "Biodiversity, Climate and Global Change" (Direction Generale VI, Brussels, Belgium).

- "Functional Importance of Biodiversity" as a focus of the international congress of the Gesellschaft für Ökologie (Society of Ecology) in Basel, Switzerland, August 2001.

- "Clearing House Mechanism-Biodiversity" by the Federal Office for Nature Conservation in Germany.

- Sounding out "Management of Biodiversity" within the Framework "Socio-Ecological Research" of the Federal Ministry of Education and Research in 2001.

- "Species Richness in Agro-Ecosystems" as a focus for a meeting of the working group of the senate of the research institutions of the Federal Ministry for Consumer Protection, Food and Agriculture.

This list could be extensively continued.

While in ecological sciences the use of the term "diversity" as a precursor of the actual term "biodiversity" has a scientific background and is fixed to clearly defined rules which have been derived from information theories (Shannon, 1948; Wiener, 1948; Shannon and Weaver, 1963), "secondary users" such as politicians and other groups of society or other branches of science that do not belong to ecological sciences treat the term "biodiversity" in a very individual and sometimes confusing manner.

Following scientific understanding, (bio-)diversity consists of two components, the diversity component and the expression of dominance structure (frequency and percentage of each element within the whole subset considered). So, the same level of biodiversity can be achieved by a considerable richness of (different) elements or by less richness but a balanced frequency of each element. An exact interpretation is possible using the term "evenness" (probability of selecting a certain element taken from a whole subset; Stugren, 1978).

However, in common use (and mainly by "secondary users") the "frequency"-component and its interpretation by the mathematically clearly defined term "evenness" is mostly neglected, so that the term "biodiversity" is actually very often used to express in an almost diffuse sense the number of different elements (mostly species) within a subset (in many cases also not clearly defined) underlayed by a "the-more-the-better"-interpretation.

More recent interpretations of the term "biodiversity" are not only restricted to "species richness", but are also related to varieties, races, life forms and genotypes as well as landscape units, habitat types, structural elements (e.g. shrubs, stonewalls, hedgerows, ponds), crop or land use diversity, etc. Finally, the term (bio-)diversity is used in areas with only a very indirect relation to the biological component of biodiversity (e.g. diversity of professions, building styles or types of cars in a defined region or community).

Hence, the generic term "biodiversity" forms an hierarchic system relevant for different scale levels (population, species, biocoenosis, habitat, landscape), compositions (sum of elements of a genome, a population, a species community, an ecosystem or a landscape) and functions (processes that run in different scale levels within the hierarchic system mentioned above) as expressed by Noss (1990).

The quality and/or quantity of a component of a higher (scale or hierarchic) level has a direct effect on the quality and/or quantity of components in lower (scale or hierarchic) levels (Waldhardt and Otte, 2000). For example, a change of the landscape pattern (structural component) as a result of a change in land use (functional component) affects the species composition (compositional component) and finally, processes 
running in ecosystems (functional component). However, the interrelations between scale (hierarchic) levels can also be the other way round, as so called "ecosystem engineers" (Jones and Lawton, 1995) may influence structures and processes in ecosystems (e.g. wild deer and big game by grazing and destruction of tree bark, the beaver by stemming the flow of streams and rivers or finally birds by distributing seeds and insects by pollination).

This background explains:

- that "biodiversity" is based upon many interlinked mechanisms which depend on the heterogeneity or "richness" of their elements in the same way as on the development of functional processes;

- that the knowledge of rules within and between the components and the hierarchic scale levels is a basic requirement for a sound interpretation of the data recorded, and for the development of advanced concepts on biodiversity management.

Particularly in applied research, functional aspects of biodiversity and consequently also structural components of agricultural ecosystems are increasingly important. Although there is no doubt about the ethical justifications of maintaining and recovering biodiversity (e.g. introduction of structural and not cultivated landscape elements in the marginal areas of cultivated fields), only little is known about whether a certain (higher or lower) biodiversity level or different dominance structures of species communities do influence the functionality of food webs, or whether the quality (and quantity) of the biological control (by natural enemies) of pest organisms in agro-ecosystems is affected (e.g. Scheu, 1999, 2001). The opinion even exists that an efficient regulation of pest organisms could be better achieved by promoting a high abundance of a limited number of predator or parasitoid species rather than by supporting a maximised diversity of these natural enemies accompanied by a low abundance level of each species (Wetzel, 1993).

Gaston (1996) highlighted three general points of view regarding biodiversity:

- Biodiversity as a concept (expressed as the "variety of life" it is completely abstract and extremely difficult to understand).

- Biodiversity as a measurable entity.

- Biodiversity as a social/political construct.
Biological diversity is concentrated in areas inhabited by socio-economically marginal and traditional societies, and so it is a key indicator of sustainability and buffering capacity: highly diverse ecosystems are, for instance, more efficient in capturing energy, water, nutrients and sediments than homogenous systems (Saxena et al., 1999). Thus, the high technical standard of central European societies seems to be a contradiction to achieve considerable biodiversity levels. However, within each level gradual differences are realised, so that the goal has to be the upper end of the level that is achievable under the conditions given. This is also valid for farmland.

\section{Biotic indicators-approaches for definitions, nomenclature, requirements and rules}

Paoletti (1999a,b) defines a bioindicator as "a species or assemblage of species that is particularly well matched to specific features of the landscape and/or reacts to impacts and changes"; the term can be described as a label for a particular situation and environmental condition.

"Biodiversity" will never be more than an umbrella for the total range of life expressions, and cannot be measured per se (Von Euler, Vancouver, Canada, personal communication, 2000*). ${ }^{1}$ As research has shown biodiversity per se has no operational definition; therefore, an indicator to assess "biodiversity" as a whole is theoretically and practically impossible (e.g. Duelli and Obrist, 2003; Lawton et al., 1998; Watt et al., 1997). Thus, the development of 'biodiversity assessment tools', or sets of indicators, that together will allow the estimation of trends in biodiversity, is suggested (Watts, Scotland, UK, personal communication, 2000*).

Besides species diversity "biodiversity assessment can rely on the number of life forms, (plant) functional types, strategic types and other typological units as well as other qualities of biodiversity as the variability between objects (e.g. heterogeneity, similarity) or the ecological complexity (resulting from interactions

\footnotetext{
${ }^{1}$ Citations marked with an asterisk and "personal communication" refer to statements within an electronic conference on "Biodiversity Assessment and Indicators", November 1999-January 2000 (http://www.gencat.es/mediamb/bioind).
} 
between the units). Concluding, it is necessary to relate biodiversity indicators within a defined space and time to specific criteria as, for example, morphological or more general spatial structures, phylogenetic similarity or functional traits" (Beierkuhnlein, Rostock, Germany, personal communication, 2000*).

Majer (1983) and Pankhurst (1994) stated that indicators: (a) should be holistic, but closely related to the assessment goals, (b) are important to the structure and function of the agro-ecosystem, (c) are a response to a range of environmental stresses, (d) can be easily measured, quantified and interpreted and (e) show an integrative potential in the long term (Lobry de Bruyn, 1997).

\subsection{Preconditions to biotic indicators}

Beierkuhnlein (Rostock, Germany, personal communication, 2000*) has developed four preconditions to judge a biotic indicator as appropriate:

- Occurrence and distribution: "biodiversity indicators have to be common and widespread. They should occur under the different environmental conditions that are of relevance according to the qualities of biodiversity under consideration".

Comment: The second sentence is essential to avoid misinterpretation. Nevertheless, there is still the danger of misunderstandings, and it depends on the purpose an indicator is created for: For instance, a species that indicates a status of higher intensification might be common and widespread whereas a species typical for a status indicating the "maturity" of a habitat, which is rarely achieved (e.g. so called "primeval forest relict species" in forests) per se cannot be "widespread and common", because of its special demand on the habitat status. So, "common and widespread" can only be regarded as a theoretical value revealing geographic distribution, climate, etc. that makes the occurrence of the species potentially possible.

- Persistence: "biodiversity indicators have to be closely connected to certain areas or spatial units. It seems to be problematic to look at species which use different habitat types or communities with low spatial and temporal constancy. The life time of indicators has to cover the life time of the objects whose diversity is addressed".
Comment: This criterion seems to be rather contradictory with regards to the demand for an indicator to be widespread and common. Secondly, if species that use different or fast changing habitats were excluded, it would be difficult to assess the biodiversity of agricultural habitats as habitats of "low spatial and temporal consistence" per se. For instance, limicoles that use a pond habitat as a food source for a short time or epigaeic predators temporarily invading a field to feed on pests create a certain diversity and so can be useful indicators for functional traits of a habitat.

- Identification: "indicators of biodiversity must be easy to identify. There should be an agreement concerning their classification and terminology. Objects with only temporal or cryptic occurrence or unclear terminology are not appropriate". Nor are objects which are costly and accessible to only a few experts.

- Sensitivity: "biodiversity indicators have to react sensitively to changes in certain forms of biodiversity. They can indicate qualitative and quantitative aspects of comparable units. For instance, the occurrence of certain species of trees (e.g. Salix spp.) might indicate a large variety of insects connected with this habitat, the occurrence of other species (e.g. Fagus) might indicate low diversity. Or, the occurrence of certain communities might indicate a certain degree of the intensity of land use and thereby a certain diversity of other communities".

Comment: This criterion can also be contradictory to some criteria mentioned above; for instance, a "common and widespread" species which presumably should have a high tolerance to several conditions may not be able to fulfil the demands on sensitivity.

The critical comments show that it is nearly impossible to create basic rules or criteria for biodiversity indicators due to the high diversity of goals indicators have to serve for. Concluding, the definitions, limits and basic demands which are related to an indicator have to be stated case by case. It, therefore, seems to make little sense to develop general definitions or criteria for biotic indicators: definitions and/or descriptions should be stated instead as the case arises (occurrence and distribution, persistence, identification, sensitivity and many more). 
The problem of using focal species, umbrella species, flagship species: keystone species. Indicators have been used to monitor economics for many years but no economist depends on a single indicator. Similarly, several ecologists have argued for sets of indicators (e.g. Stork, 1995; Stork and Eggleton, 1992; Ferris and Humphrey, 1999).

Lambeck (1997) suggested selecting an array of "focal species" which are specialised and sedentary ( $\geq$ K-strategists) thus showing a considerable sensitivity towards area, resources, dispersal and process limitation. If the landscape was managed for the conservation of these species most other species would also be conserved. The concept to use "focal species" has been applied mostly to nature conservation purposes up to now and has focused on (large) threatened species with a high sensitivity (e.g. top predators) of public interest. However, it is also imaginable for the assessment of beneficial potential in an agricultural habitat. According to Aarts (Nijmegen, The Netherlands, personal communication, 2000*) "focal species are just very sensitive creatures, but not intrinsically important to the functioning or the stability of the ecosystem" (which are covered by the term "keystone species"; e.g. Naeem and Li, 1997; Scheu, 1999). Thus, due to the experience of a lot of scientists, for example, in central Europe the carabid beetle Carabus auratus can be assumed as a species which indicates an acceptable standard of an agro-ecosystem with regards to epigaeic predator activity including some traits on functional biodiversity "ecosystem health". Due to the fact that the assessment of biodiversity per se will not be realistic in particular for routine evaluations, the restriction to a set of "focal species" which are easy to identify and to assess seems to be one solution to handle the problem.

However, when using "focal species", "flagship species" or "umbrella species" as representative units for a certain status, a serious validation of the potentials and limits (concerning all aspects) is essential. This essential precondition is usually neglected; "focal species" are used for more superficial reasons such as public acceptance, extent, and a more or less nebulous concept of their ecological potential. In most cases the second step (application as an indicator) is often carried out before the first (validation of potentials and limits as an indicator), i.e. a correlation between these species and biodiversity is claimed, but remains untested as well as the criteria for the choice of those umbrella and flagship species.

Andelman and Fagan (2000) who analysed the effectiveness (regarding number of protected species and costs) of a range of different surrogate schemes (e.g. large carnivores, charismatic species, key-species and wide-ranging species) on three different geographical scale levels (habitat ecoregion [= natural unit] and state) found a limited suitability of umbrella and flagship species as surrogates for regional biodiversity. According to Good (Cork, Ireland, personal communication, 2000*) flagship species might have a potential to indicate threatened species; they will rarely represent the complexity of habitat species diversity, in particular regarding the interpretation of management impacts. He points out that for habitat species diversity, indicators of ecological integrity are needed, interpreted as the specialist ability of ecosystems to deal with their climatic and edaphic environment, as well as specific soil/organic microenvironments with their own diversity of soil microorganisms (see Schloter et al., 2003).

The "focal species approach", and even more the "keystone species approach", depend upon knowledge of the ecology of the chosen species, which is available for taxonomically and faunistically well known groups (e.g. vertebrates, carabids, spiders, Rhopalocera) but may be sparse for the majority of invertebrate taxa (e.g. mites, Diptera, parasitic Hymentoptera and Coleoptera in general).

If focal/keystone species are introduced for management of biodiversity, regular monitoring is required. However, hardly any evidence can be found in recent literature on the intervals at which the monitoring of biodiversity or sustainable land use should be repeated, although no habitat type is free of changes. But regular monitoring intervals also imply that not only an actual status or the actual functionality of a process is recorded, but that these assessments are essentially combined with a well defined target to be achieved.

\subsection{Categorisation of indicators}

Döring et al. (2003, and in litteris) separates "goal indicators" and "status indicators". As "goal-oriented indicators", species are described which show that a defined status is achieved, a "status-oriented indicator" says something about the actual status of the field 
(e.g. regarding biodiversity). Stenotopic field species among carabids are suggested as "goal-oriented indicators", xerophilic, herbivorous arthropod species as "status-oriented indicators" for biodiversity, and the zonation types of the weed flora communities for management intensity. However, an indicator is not intrinsically a "goal" or a "status" indicator: the purpose for which an indicator is used is defined by the researcher through the goals or results which should be achieved and not by the indicator itself. For instance, producing a certain zonation type of field vegetation can also be a goal, on the other hand the percentage of stenotopic field carabids can provide information on the actual status of a field.

\subsection{Indicator purposes}

Duelli and Obrist (2003) differ between indicators for biodiversity (e.g. measuring the effect of heavy metal contamination on biodiversity as such) and indicators from biodiversity (e.g. effects of a heavy metal contamination on a certain taxonomic group). However, a good indicator for environmental pollution (e.g. heavy metals) must not indicate biodiversity (if it is not linearly correlated to biodiversity).

The complex background of using bioindicators for biodiversity can be summarised by the following:

- there is no consensus on how to use bioindicators;

- there is no indicator for biodiversity as a whole;

- each aspect of biodiversity (and also each goal for using indicators) needs its own indicator with very specific and well defined features and agreements on the mode of application.

For this purpose Duelli and Obrist (2003) developed a hierarchy of indicators and distinguished between three kinds of indicators for "nature protection", "plant protection" and "ecological resilience". Each of these three goals requires a different kind of indicator which will provide different values for biodiversity.

Nature protection (diversity of threatened species), tested by the number of threatened or rare species; (problems: national/international importance of threatened species, availability of Red Lists which cover only 7\%; typical taxa used for conservation purposes as, e.g. butterflies, grasshoppers, birds cover only $1 \%$ of all species in agro-ecosystems so that this goal is not appropriate to evaluate agro-ecosystems).
Plant protection (diversity of beneficial organisms), tested by the abundance (short-term assessment) and species numbers (long-term assessment) of beneficials such as epigaeic and aphidophagous predators, parasitoids and key decomposers; predators are preferred to parasitoids because they are easier to assess and more is known on their ecological demands; the set up of ratios between herbivores and predators or parasitoids is conceivable following the habitat template-hypothesis of Brown and Southwood (1987).

Ecological resilience (species diversity of all organisms) tested by a set of selected taxa, e.g. Aculeate Hymenoptera, Heteroptera, and flowering plants, or a representative sample of all arthropods referred to a certain sampling method. (Problems: assessment of ecological resilience is based on the entire biodiversity as it is assumed that a higher number of different species, genes, etc. correlates with the functionality of ecosystems - for routine assessment too laborious and cost-intensive).

Finally, Duelli and Obrist (2003) recommend to pool the resulting indicators for each motivation, and the respective values to form an index which is similar to economical indices like the Dow Jones.

A similar approach, but more related to ecosystem features than anthropocentric goals has been developed by Good (Cork, Ireland, personal communication, 2000*) using soil staphylinid beetle assemblages as an indicator system for:

- productive systems (e.g. arable crops) considering the abundance of beneficial species (predators) only;

- self-sustaining ecosystems (e.g. revegetated mine waste) considering only a selected set of species associated with ecosystems not receiving external nutrient inputs and associated with litter decomposition;

- biogeographically characteristic ecosystems (e.g. calcareous fens) considering species which are of local occurrence and stenotopic.

Relying on McGeoch (1998), Lawton and Gaston (2001), Perner and Malt (2003) categorise indicators into environmental indicators (reflecting the biotic/abiotic state of an environment), ecological indicators (indicating impacts of environmental changes), and biodiversity indicators (indicating the 
diversity of species, taxa or entire communities in relation to habitat or area).

Döring et al. (2003) distinguish between four types of indicators:

- biotic indicators for abiotic status;

- biotic indicators to evaluate husbandry practices;

- goal parameters which can be derived from the (protection) goals agreed on beforehand;

- correlates or surrogates of goal parameters that minimise time, effort and costs with the disadvantage of information losses due to the simplification of data.

\subsection{Assigning values to indicators-establishment of priorities}

Assigning a "value" to different (indicator) species and other biodiversity facets and in consequence, the establishment of clear priorities seems unavoidable. In the absence of an open and formal value system, priorities will still be made, but based on hidden value systems which are beyond critical examination. (Von Euler, Vancouver, Canada, personal communication, 2000*).

Alpha-diversity (richness of species, gene alleles or other "taxonomical" units) can be interpreted in two ways according to Duelli and Obrist (2003):

(a) Each species (or other taxonomical unit) is valued equally: the species number correlates linearly to biodiversity.

(b) Each species is valued equitably (e.g. rare or threatened species for conservation purposes or predators for pest control) depending on its significance for reaching the goal. Regarding conservation purposes the ranked value depends, for instance, on the spatial level at which a species is threatened (e.g. local, national, international, global), with regards to biocontrol purposes (plant protection) on the predatory capacity, its local abundance and the gradual preference of a certain prey.

Within the latter (species as natural enemies in pest control) the term "functional biodiversity" becomes more significant. According to Duelli and Obrist (2003) "structural and functional diversity is somehow reflected in the number of species". It is assumed that more trophic levels (or functional groups, respectively) automatically include more species, and that higher structural diversity (in its widest sense; e.g. Noss, 1990) will provide more ecological niches. Apart from conservation purposes, for instance, biocontrol would be more efficient and in the long term more sustainable if a higher (species-)biodiversity is achieved. This reflects the "niche-complementhypothesis". Other hypotheses (Lawton, 1994) like the "redundancy hypothesis" (see Perner and Malt, 2003) assume that functional effects of biodiversity show an asymptotic function, i.e. if a certain number of species is exceeded, more species will not improve ecosystem functions; the "idiosyncratic hypothesis" supposes that functional effects of biodiversity are not predictable and thus occur stochastically on the basis of some "keystone species" which catalyse ecosystem functions, whereas other species are redundant (see Scheu, 1999). The latter hypothesis is subliminal and is often used in applied agricultural research relying on "beneficials" (e.g. Wetzel, 1993) which are determined as "keystone elements" from an anthropocentric point of view. However, apart from some more general and model-like assumptions that a higher biodiversity would narrow the food web so that a functional replacement of an extinct species could be counterbalanced more easily (Naeem et al., 1994; Naeem and Li, 1997; ${ }^{2}$ McGrady-Steed et al., 1997; Tilman et al., 1997), very little scientifically sound data from field experiments can be found in recent literature to support this assumption (e.g. Maraun et al., 1998).

\subsection{Taxa and their suitability as indicators}

Appropriate indicator species should perform:

- a low coefficient of variance for the mean number of individuals recorded per site;

- a high degree of habitat preference for the habitat considered (Perner, 2003);

\footnotetext{
${ }^{2}$ All these results are elaborated under very artificial circumstances (in laboratory microcosms) and on the basis of microorganisms (e.g. bacteria, algae and protists) and at least Collembola as representatives of decomposers and mesofauna (Naeem et al., 1994; Naeem and Li, 1997), on the basis of plant communities (Tilman et al., 1997) or in aquatic ecosystems (McGrady-Steed et al., 1997). However, producing an artificial "biodiversity" by adding selected species of functional groups to a microcosm according to the belief of the researcher is far away from the complex interrelations which are in reality in the field, particularly if higher taxonomic levels are considered.
} 
- a potential high biodiversity;

- a good niche separation (Nickel and Hildebrandt, 2003).

In a 3-year survey on the conversion of arable land into grassland with six different management systems and its effect on vegetation, spiders and beetles, it could be shown by Perner and Malt (2003) that:

- Regardless of taxon, invertebrates were more suitable than vegetation for showing a difference in the effects of the conversion types.

- Spiders (Arachnida: Araneae) and beetles (Insecta: Coleoptera) showed clear reactions to changes of microclimatic conditions and soil humidity; hydrophilic spider and beetle species were identified as "quick assessment tools", referring to the high potential of spiders to recolonise rapidly by ballooning, or the ability of macropterous beetles to fly.

- The advantage of invertebrates as indicators compared to vascular plants resulted in a shorter delay period for the reaction of the taxa to changes that could be correlated mainly to microclimate and soil moisture (an indication of these changes is already visible after 3-5 years). The minor suitability of vegetation as a short-term indicator is explained by the fact that the seed bank of (intensively managed) arable fields is getting continuously poorer.

- The seed distribution (spreading of seed) is heavily reduced particularly for plant species of later succession stages.

- Weed species (e.g. Cirsium arvense, Galium aparine, Elymus repens) are strong competitors for power compared to other plant species (particularly on humid soils), so that a development of diverse plant communities is restricted for many years after conversion.

Thus, the reaction of the vegetation is obviously less appropriate for indicating short-term regeneration processes, but more suitable for detecting long-term changes. Therefore, Perner and Malt (2003) recommend a combination of vegetational and invertebrate monitoring particularly when land use changes have just been introduced.

The indication potential of herbivorous insects has almost been neglected up to now, in particular those which are closely related to vascular plants typical for field habitats. Whereas plant seeds are mostly able to persist for years in the soil, monophagous herbivores will become (locally) extinct after just one season without finding their host plant species. Thus, compared to vascular plants, an exponential higher sensitivity to environmental changes (e.g. by husbandry practice) is assumed. Köhler (1998) and Fritz-Köhler (1996) showed, for instance, that leaf beetles (Coleoptera: Chrysomelidae) and weevils (Coleoptera: Curculionidae) feeding on field weeds are excessively endangered compared to other taxa: $5.6 \%$ of all polyphagous, $8.5 \%$ of all oligophagous and $13.1 \%$ of all monophagous species from these beetle families have been missing for more than 50 years. Furthermore, Köhler (1998) highlighted that the number of individuals per species will increase if more extensive management (e.g. no herbicides and fertilisers) is conducted.

While plant species richness can be recovered easily and rapidly from the seed potential in the soil if conditions become more favourable, herbivore insects are influenced by several factors as, for instance, management intensity, structural performance of the landscape, the connectivity of habitats, etc. Therefore, the occurrence and abundance of mono- and oligophgous herbivores can be judged as very sensitive cross-section indicators of an overall positive development of agricultural habitats.

Nickel and Hildebrandt (2003) recommend herbivorous invertebrates (in particular Auchenorrhynchacommunities) as suitable biotic indicators for habitat disturbance, particularly in comparison to plant communities due to:

- great abundance (>1000 ind $/ \mathrm{m}^{2}$ in grassland ecosystems) and large species numbers (approximately 320 in grasslands) which allow clear and gradual assessments of management effects or environmental loads;

- a high species richness positively correlated with higher species diversity of other taxa as, e.g. Heteroptera, Saltatoria, Rhopalocera (Achtziger et al., 1999), vascular plants and their structural complexity and spatial composition (Denno, 1994; Denno and Roderick, 1991; Murdoch et al., 1972);

- a rapid reaction to management intensity by changes in dominance structure and species community 
(Andrzejewska, 1976, 1991; Morris, 1973, 1981a,b, 1992; Morris and Plant, 1983; Morris and Rispin, 1987; Nickel and Achtziger, 1999; Prestidge, 1982; Sedlacek et al., 1988);

- separation into several life strategies (e.g. macropterous/brachypterous; uni-/bi-/polyvoltine; mono-/ oligo-/polyphagous) which are directly correlated to environmental conditions (Novotný, 1994a,b, 1995) (see r-K-selection, Table 2);

- importance as prey items for predators (e.g. spiders, ants, birds such as partridges) and hosts for parasitoids, the amount of which can be estimated as an indicator itself (see Moreby and Aebisher, 1992, Potts, 1986);

- their focus as primary consumers on the vegetation layer and their function as vectors of plant diseases (e.g. viruses, MLOs); thus, they influence the composition of plant species and their competition power (Curry, 1994);

- the suitable and easy application of sample methods for the assessment of abundance (D-Vac suction trap samples) and species composition (sweep net samples);

- the easy estimation of reproductive success by counting the number of nymphs in the samples.

The level of taxonomical knowledge required makes the use of Auchenorrhyncha as biotic indicators more difficult and is an obstacle to a broad and easy application.

Testing several invertebrate taxa Duelli and Obrist (2003) found that bugs (Heteroptera), wild bees (Apidae), and wasps (Hymenoptera aculeata) showed the best correlation, while spiders and ground beetles showed poor correlation to entire species richness when used as indicators for ecological resilience.

In Australia soil biota have been identified as bioindicators of soil sustainability in agricultural land (Pankhurst et al., 1995; Hamblin, 1992; SCARM, 1993), but as in Europe, validation by field experiments is lacking. In this context, Lobry de Bruyn (1997) stresses the importance of ants as soil indicators due to their species richness (1100 species) in Australia. Radford et al. (1995) and Wang et al. (1996) showed that in agricultural soils biodiversity and abundance of ants increases when minimum tillage and stubble retention is applied. Comparing different farming systems in central Europe Büchs et al. (1999) identified ants as indicators for an extremely extensive management (no pesticides, no fertilisers, extensive rotation) or set-aside. Dauber et al. (2003) include ants in an indicator concept considering a landscape matrix. However, according to Linden et al. (1994) and Lobry de Bruyn (1997) the value of ants as indicators of soil quality remains unclear. Their functions in agro-ecosystems have to be elucidated and their role in soil processes quantified; finally, taxonomic tools are required which enable non-specialists for identification. Lobry de Bruyn (1997) estimates ant indicators as part of a broader system of ecosystem process indicators.

Diptera are mostly myco- or saprophagous and fulfil keystone functions as soil-dwelling larvae within the decomposition of plant residues. However, determination is laborious and requires great skills. Diptera could be identified as indicators for management intensity and environmental loads (e.g. fertilisers and pesticides) by Franzen et al. (1997) and Weber et al. (1997) on the community as well as on the population level. It could be demonstrated that dominance structure was affected according to the pesticide and fertiliser input and became less complex and balanced the more intensive production means were used. A clear correlation of emergence rates to management intensity as regards pesticide and fertiliser input could be observed in (mostly fungivorous) gall midges (Diptera: Cecidomyiidae) and on the population level (sometimes crop-specific) for dominant Sciaridae (fungus gnats) species (e.g. Scatopsciara vivida (Winnertz, 1867), Lycoriella castanescens (Frey, 1948), Corynoptera dubitata (Tuomikowski, 1960)). Prescher and Büchs (1997, 2000) showed that pest species of the genus Delia spp. (Diptera: Anthomyiidae) were negatively correlated with increasing extensification. Currently Sciaridae are tested as monitor organisms to indicate effects of GMO-crops on decomposition processes (Büchs et al., unpublished). Frouz (1999) highlights the potential of using morphological deformities in the context of "fluctuating asymmetry"; which has been mainly tested up to date with aquatic communities (Nematocera: Chironomidae), but also in terrestrial habitats using left-right asymmetry of wing venation (see Table 1).

In contrast to other Diptera, taxa determination of adult hover-flies (Diptera: Syrphidae) is comparatively easy. Life forms of larvae represented in a 
Table 1

Selection of indicators, indication systems and approaches to indications on the basis of animal populations or species communities with special reference to agro-ecosystems ${ }^{\mathrm{a}}$ and direct or indirect effects on biodiversity and/or sustainable agriculture

\begin{tabular}{|c|c|c|c|}
\hline Indication parameter/level of indication & Indication goal & Taxon & References \\
\hline \multicolumn{4}{|l|}{ Population } \\
\hline Digestive enzymes & $\begin{array}{l}\text { (Heavy metal) toxicity of } \\
\text { soils }\end{array}$ & Isopoda & Joy et al. (2000) \\
\hline Nutritional conditions & $\begin{array}{l}\text { Food supply (management } \\
\text { intensity) }\end{array}$ & Carabidae & $\begin{array}{l}\text { Van Dijk (1986), Wallin (1989), } \\
\text { Chiverton (1988), Zanger et al. (1994), } \\
\text { Langmaack et al. (2001) }\end{array}$ \\
\hline Growth rate & Habitat quality & $\begin{array}{l}\text { Araneae (orb-weaving } \\
\text { spiders) }\end{array}$ & $\begin{array}{l}\text { Marc et al. (1999), Nyfeller (1982), } \\
\text { Vollrath (1988) }\end{array}$ \\
\hline $\begin{array}{l}\text { Mean body weight restricted to } \\
\text { populations of selected species }\end{array}$ & $\begin{array}{l}\text { Management intensity; } \\
\text { disturbance }\end{array}$ & Carabidae & Büchs et al. (2003), Zanger et al. (1994) \\
\hline $\begin{array}{l}\text { Mean body size restricted to } \\
\text { populations of single species }\end{array}$ & $\begin{array}{l}\text { Management intensity; } \\
\text { disturbance }\end{array}$ & Carabidae & Büchs et al. $(1999,2003)$ \\
\hline Development of wing muscles & $\begin{array}{l}\text { Disturbance; environmental } \\
\text { stress }\end{array}$ & Carabidae, Staphylinidae & Geipel and Kegel (1989), Assing (1992) \\
\hline Egg production & $\begin{array}{l}\text { Food supply; (management } \\
\text { intensity) }\end{array}$ & Carabidae & Van Dijk (1986) \\
\hline Abundance & $\begin{array}{l}\text { Environmental stress } \\
\text { (management intensity) }\end{array}$ & Carabidae & Büchs et al. (1997), Döring et al. (2003) \\
\hline Web size, web structure & $\begin{array}{l}\text { Environmental stress (e.g. } \\
\text { pesticide effect; prey supply) }\end{array}$ & Araneae & $\begin{array}{l}\text { Retnakaran and Smith (1980), Riechert and } \\
\text { Harp (1987), Roush and Radabaugh (1993) }\end{array}$ \\
\hline Fluctuating asymmetry & Environmental stress & Several insect taxa & $\begin{array}{l}\text { Palmer and Strohbeck (1986), Warwick } \\
\text { (1988), Clarke (1993), Krivosheina } \\
\text { (1993, 1995), Rahmel and Ruf (1994), } \\
\text { Vermeulen (1995) }\end{array}$ \\
\hline $\begin{array}{l}\text { "Ellenberg" indicator values } \\
\text { for vascular plants }\end{array}$ & $\begin{array}{l}\text { Abiotic demands (e.g. soil } \\
\text { humidity, moderate } \\
\text { temperature, etc.) of } \\
\text { invertebrates }\end{array}$ & (Epigaeic) invertebrates & $\begin{array}{l}\text { Perner and Malt (2003), Stumpf } \\
\text { (personal Communication, 1996) }\end{array}$ \\
\hline Hibernation behaviour & $\begin{array}{l}\text { Landscape structures; } \\
\text { management intensity }\end{array}$ & Staphylinidae & D'Hulster and Desender (1984) \\
\hline \multicolumn{4}{|l|}{ Community } \\
\hline Number of morphospecies & Species richness & Several invertebrate taxa & Duelli and Obrist (2003) \\
\hline $\begin{array}{l}\text { Presence and abundance of } \\
\text { species combination }\end{array}$ & $\begin{array}{l}\text { Humus and peat bog } \\
\text { content in soils }\end{array}$ & Rana arvalis, Sphagnum spp. & Kratz and Pfadenhauer (2001) \\
\hline $\begin{array}{l}\text { Number of species, mortality, } \\
\text { parasitism }\end{array}$ & $\begin{array}{l}\text { Species richness, habitat } \\
\text { fragmentation, disturbance }\end{array}$ & Trap-nesting bees and wasps & Tscharntke et al. (1998) \\
\hline
\end{tabular}
Comments/description

Some approaches are more indirect and more related
to reproduction (Van Dijk, 1986; Wallin, 1989); some allow to reproduction (Van Dijk, 1986; Wallin, 1989); some allow
direct assessment by gut dissection (Chiverton, 1988; Zanger et al., 1994; Langmaack et al., 2001)

Assessment of habitat quality due to (estimated) food intake and (measured) growth rates. Standard calibrated values recorde in the lab were applied to field conditions

Body size of adults changes depending on current life conditions (e.g. prey supply). Does not function with adult conditions (e.g. prey supply). Does not function with adult
stages of univoltine holometabolous insect species, because body size is fixed with metamorphosis and depends on life conditions of larval stage which possibly developed in different conditions and locations

Correlation of abundance to environmental stress or managemen intensity obvious, but no correlation between abundance and species diversity could be detected

Up to present mostly applied in urban ecology or aquatic ecosystems; no experience in agricultural ecosystems

Survey of the vascular plant community in the catchment area of, e.g. pitfall traps and determination of their Ellenberg values. In a second step the values are related to invertebrate species recorded in the pitfall trap samples

Range of error varies depending on the difficulties and efforts to separate species morphologically (e.g. whether preparation of sexual organs is necessary) and the skill level of the researcher Restricted to originally moorland locations

Easy method to apply: artificial units of reed internodes are placed in the habitat considered. Assessment of no. of colonised reed internodes, mortality by trap-nesting bees and wasps, species set of predators and parasitoids 
Taxonomic distance, taxonomic distinctnes

Zoogeographic and taxonomic structure related to different spatial scales

Dominance structure of species communities

Classification of species int $\mathrm{r}-\mathrm{K}$-continuum Habitat preferences

Percent stenotopic field species

Percent euryoecious species

Percent pioneer species

Percent Lycosidae

Ratio of predators and prey

Relation of phyto- and

saprophagous to carnivorous

correlated to the average body

size

acropterous vs.

brachypterous species/individual

Ash-free dry weight; ash weigh

Mean or median of body size of species community

Percent juveniles; percen nymph
Sensitive indication of environmental perturbation

Environmental impacts

Environmental stress soils

Disturbance; environment

Management intensity; disturbance

Management intensity;

disturbance

Management intensity,

disturbance

Management intensity,

disturbance

Management intensity: disturbance

Management intensity;

environmental stres

"Habitat maturity";

management intensity

"Maturity" of a habita

management intensity

Functional importance environmental

management intensi

Management intensity;

disturbance

Reproductive

success-management

intensity; disturbance
Auchenorrhyncha, Syrphidae, soil mites (Oribatei)

Nickel and Hildebrandt (2003), Good and Speight (1991), Speight et al. (1992), Siepel (1994, 1995, 1996)

Ecosystem or biome-relate biocoenosis; birds

Carabidae

Soil mites

Nematoda, Gamasina

Araneae

Carabidae; Syrphidae

Araneae

Araneae, Auchenorrhyncha

Araneae

Several arthropod tax

Coleopter

Carabidae; Auchenorrhynch

nchytraeidae

Carabidae, Staphylinidae,

Araneae

Araneae, Auchenorrhyncha
Warwick and Clarke $(1998,1999)$, Clarke and Warwick (1998), Von Euler (1999)

Popov and Krusteva (2000)

Hagvar (1994)

Bongers (1990), Ruf (1998)

Büchs et al. (2003)

Döring and Kromp (2003), Haslett (1988)

Büchs et al. (1997)

Büchs et al. (1997, 2003), Nickel and Hildebrandt (2003)

Büchs et al. (2003)

Brown and Southwood (1987), Greiler and Tscharntke (1991) Sampels (1986)

Den Boer (1968, 1977), Döring and Kromp (2003), Gruschwitz (1981), Nicke and Hildebrandt (2003)

Van Vliet et al. (1995)

Steinborn and Heydemann (1990),

Köhler and Stumpf (1992), Blake et (1994), Buch at al (1997, 1999, 2003), Döring and Kromp (2003) Doring and Kromp (2003) Hildebrandt (2003)
The comparison is based on certain ecological features

(e.g. mono-/oligo-/polyphagous species; macro-/brachypterous

species-Auchenorrhyncha) or larval life forms (Syrphidae).

For mites life strategies and life-history patterns of supraregion surveys are compared to those of the study sites

Total genetic components of a biome may remain constant but be partitioned differently among the hierarchy of taxonomic un

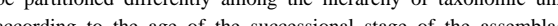
A two-way indicat species alysis is applied at difent secte A

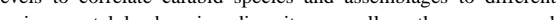

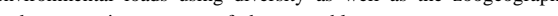
and taxonomic structure of the assenblages

Change of dominance structure in the soil microarthropod

communities is suggested as an indicator of various

Index of "maturity": classification of species into the -K-continuum depending on the type of reproduction

Veritable database available regarding ecological characteristic

of central European spiders: Maurer and Hänggi (1990), Nentwi et al. $(2000)$

See text

Considerably weaker than \% "pioneer species"; veritable database regarding ecological characteristics of central European spiders by Maurer and Hängi (1990) and Nentwig et al (2000) pides by econg and Hänggi (1990) and Nentwig et al. (2000)

Indicator easy to apply, becuse separation of wolf spiders from samples requires only low skill level; determination of species level not obligatory

Assessment based on the "habitat template-hypothesis" of Brow and Southwood (1987)

Index of "habitat maturity" was applied in vineyards and is mos suitable in permanent crops such as vineyards, orchards, china grass, etc.

Macropterous carabids/plant hoppers are said to be typical for (frequently) disturbed ecosystems; brachypterous insects for more mature ones; but risk of misinterpretation if forest species occur in fields

The ash-free dry weight or ash weight is suggested as a key indicator to explain the enchytreid community structure with regard to their functional role in (agro-)ecosystems

Two possibilities: purely species-related or individuals of each Two possibires pech

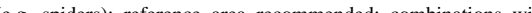
(e.g.

Juvenile wolf spiders (Araneae: Lycosidae) have to be excluded 
Table 1 (Continued)

\begin{tabular}{|c|c|c|c|c|}
\hline Indication parameter/level of indication & Indication goal & Taxon & References & Comments/description \\
\hline \multicolumn{5}{|l|}{ "External" surrogates } \\
\hline Soil quality index & Species diversity & Carabidae & Brose (2003) & $\begin{array}{l}\text { Low soil quality is correlated with high species numbers; } \\
\text { index easy to apply }\end{array}$ \\
\hline Sand content of soil; soil type & Species diversity & Carabidae, Araneae & $\begin{array}{l}\text { Irmler (2003), Perner and Malt (2003), } \\
\text { Steinborn and Meyer (1994) }\end{array}$ & Sand content is positively correlated with species richness \\
\hline Field size & Species richness & Carabidae & Frieben (1998), Irmler (2003) & $\begin{array}{l}\text { Irmler (2003) discovered a correlation between field size and } \\
\text { numbers of species; Frieben (1998) constructed a (theoretical) } \\
\text { model of the colonisable field area in relation to field size }\end{array}$ \\
\hline $\begin{array}{l}\text { Edge-to-area ratio of field } \\
\text { margins }\end{array}$ & Species diversity & $\begin{array}{l}\text { Carabidae and other epigaeic } \\
\text { predators; vascular plants }\end{array}$ & Altieri (1999), Waldhardt and Otte (2003) & $\begin{array}{l}\text { This edge-to-area indicator is completed by Boatman (1994) } \\
\text { and Frieben (1998) by an index value, e.g. for the distance } \\
\text { carabids are able to immigrate into fields }\end{array}$ \\
\hline $\begin{array}{l}\text { Length (and "quality") of } \\
\text { field margins }\end{array}$ & $\begin{array}{l}\text { Biodiversity (number of } \\
\text { species) }\end{array}$ & $\begin{array}{l}\text { Complete biocoenosis (incl. } \\
\text { plants) }\end{array}$ & Irmler (2003), Waldhardt and Otte (2003) & $\begin{array}{l}\text { Length is a consistent parameter, because it can be related } \\
\text { to field size (area); quality" needs clear definition and depends } \\
\text { on the taxon considered }\end{array}$ \\
\hline Organic farming & $\begin{array}{l}\text { Species richness; stenotopic } \\
\text { field species }\end{array}$ & $\begin{array}{l}\text { Several vertebrate and } \\
\text { invertebrate taxa }\end{array}$ & $\begin{array}{l}\text { Kromp (1999), Döring and Kromp } \\
\text { (2003), Pfiffner (1997), Irmler (2003), } \\
\text { The Soil Association (2000) }\end{array}$ & $\begin{array}{l}\text { Organic farming is introduced as a surrogate indicator for } \\
\text { biodiversity due to various results that show an increase of species } \\
\text { numbers with a habitat-typical performance; duration of organic } \\
\text { farming is an important additional criterion; however, assessment } \\
\text { restricted to organic fields, an extrapolation to the status of the } \\
\text { whole agriculturally (but not organically) used area is not possible }\end{array}$ \\
\hline
\end{tabular}


species community are the basis for a suitable indication: Müller (1991) and Ssymank (1993) showed that Syrphidae-species with zoophagous larvae (which dominate in intensively managed fields due to a high $\mathrm{N}$-fertilisers input and thus, gradations of aphids) decrease in abundance with increasing extensification of crop management in favour of an increase of species with coprophagous and filtering (saprophagous) larvae. Simultaneously the number of migrating species decreases; particularly species numbers are much higher compared to intensive management (Banks, 1959; Ssymank, 1993; Knauer, 1993).

The extraordinarily high mobility of many hover fly species and their tendency to migrations and temporal invasions, particularly the aphidophagous species, restrict the possibility of relating a species set to a certain field location, or of assessing specific impacts as, for instance, pesticide and fertiliser input, tillage, cultivars, etc. (Sommaggio, 1999). Nevertheless, since it was shown that diversity of landscape structures adjacent to fields enhance individual as well as species numbers (Banks, 1959; Knauer, 1993) and result in an earlier occurrence of aphidophagous syrphids in fields (Paoletti, 1984; Krause and Poehling, 1996), syrphid populations and species communities can be assumed as suitable assessment parameters to evaluate the success of measures implied by surrogate indicators which are based, for instance, on the percentage of "Ecological Priority Areas" (EPAs) (e.g. Roth and Schwabe, 2003; Braband et al., 2003) or other landscape-oriented measures (Waldhardt, 2003).

Alvarez et al. (2001) who characterised Collembola assemblages in conventional, integrated and organic winter wheat fields at three locations in England were able to show that community composition and species dominance are obviously influenced by farming systems, but no species could be identified as indicators for differentiating between the farming systems. Büchs (1993, 1994) and Büchs et al. (1999) showed (for various crops) that Sminthurid springtails (Collembola: Symphypleona) which feed on fungi and pollen on crop plant leaves are very reliable and sensitive indicators even at higher taxonomic levels (e.g. suborder or family) which are able to meet the demands for simplification with regards to indicator development (see further).

While oribatids (Acarina: Oribatei) are suitable indicators for air pollution (André, 1976; Weigmann and Jung, 1992; Büchs, 1988), their suitability for agro-ecosystems is limited, because the oribatid fauna of arable soils per se is dominated by species which indicate disturbance (e.g. Brachythoniidae, Tectocepheidae, Oppiidae), meaning that up to now, no specific keystone species of orbiatid mites could be identified for agro-ecosystems (Behan-Pelletier, 1999). Koehler (1999) states that Uropodina which prey on nematodes and insect larvae are suitable indicators of soil compaction and the quantity of organic material, whereas Gamasina indicate soil conditions, disturbance and anthropogenic impact. The hemiedaphic nematode predator Alliphis siculus was identified as a key species in communities which indicate sustainable agriculture.

Isopoda provide information on functional aspects of decomposition processes showing clear reactions to tillage, to the supply of decaying organic materials and to pesticide input (Paoletti, 1999a,b). Since they accumulate heavy metals (Paoletti, 1999a,b; Joy et al., 2000), they are of special interest for indicating copper residues, particularly in organic grown vineyards (Wittasek, 1987). Well developed assessment procedures exist for indicating heavy metals (Joy et al., 2000; Hopkin et al., 1993). Crop management effects can be comparatively assessed by abundance, biomass and species richness of Isopoda (Paoletti, 1999a,b; Paoletti and Hassal, 1999). Büchs et al. (1999) recorded Isopoda in fields only in considerable abundances when extensive farming or set-aside was applied.

Earthworms are estimated as suitable indicators for soil structure or compaction, tillage practice, heavy metals and pesticides (Larink et al., 1993; Paoletti, 1999a,b; Kühle, 1986; Knüsting et al., 1991). According to Paoletti (1999a,b), endogaeic earthworms are more suitable for monitoring pesticide or heavy metal residues than anecique species. Knüsting et al. (1991), however, showed that for farming systems with different pesticide input levels (beside litter supply) tillage is the main factor steering the performance of earthworm communities in agro-ecosystems. Biomass, species numbers and ecological guilds (e.g. epigaeic, anecique, endogaeic) are favoured by Paoletti (1999a,b) as key indication parameters for assessing earthworms in agro-ecosystems.

Beside the integration into an $\mathrm{r}-\mathrm{K}$-continuum, Yeates and Bongers (1999) discuss biomass of 
bacteria-feeding nematodes as well as nematode taxa with striking morphological characteristics that are easy to recognise (e.g. predacious Monochidae or plant associated genera like Paratylenchus or Gracilacus) as potential indicators. Whereas the latter Tylenchida were identified in New Zealand as indicators for the burning of field soils, the Monochidae occasionally showed a contradictory population development to earthworms, so that their use as an indicator for sustainable management is not consistent.

Fundamental works on the ecological features of central European spiders (e.g. Martin, 1972, 1973; Platen et al., 1991; Maurer and Hänggi, 1990) provide a good basis for using spiders as indicators on a species community level and can be enhanced by using mathematical procedures (e.g. CCA, TWINSPAN, PCA, DECORANA, etc.; see Marc et al., 1999; Hill, 1979; Krebs, 1999; Manly, 1992; Motulsky, 1995). As it is shown in Büchs et al. (2003) the analysis of habitat preferences enables a precise assessment of disturbances and environmental stress by crop management. In particular the ratio "spiders typical for weedy fields" versus those preferring "dry meadows" and the ratio "pioneer species" (mostly Linyphiidae) versus "wolf spiders (Araneae: Lycosidae)" are reliable indicators, meaning that they can be also used for the assessment of situations in agro-ecosystems other than management intensity, as could be demonstrated within the evaluation of several seed-mixes for rotational set-aside. Furthermore, if related to a reference area the Shannon-diversity index $\left(H_{\mathrm{s}}\right)$ and the Jaccardor Sörensen-similarity index proved to be reliable for assessing management effects on spiders. The average body size (of male spiders) also seemed to be a suitable indicator to evaluate environmental stress (Büchs et al., 1997), but is not very sensitive and functions only if fields compared are not too closely related regarding management intensity. Methodological objections are against the use of sex ratio for indication, because in the same location pitfall traps select active males to a high percentage whereas emergence traps show a balanced sex ratio. Furthermore, indication can base on the percentage of juvenile spiders (except Lycosidae) with the advantage that no species identification is necessary, on reproduction cycles (steno-, diplo-, eurychrone), phenology, preference to abiotic factors (see above), but obviously not on species richness and abundance (Büchs et al., 1997, 1999;
Kleinhenz and Büchs, 1993, 1995; Stippich and Krooß, 1997). Other approaches start from huge data bases in order to relate a site-specific spider community to supraregional species sets (e.g. Canard et al., 1999; see Table 1), partly complemented by creating values such as the community index of Ruzicka and Bohac (1994) for spiders and rove beetles (Bohac, 1999; see below), which groups species according to their occurrence in more natural or more anthropogenic influenced habitats and relates them to communities typical for undisturbed climax stages. However, it seems to be questionable whether such a procedure enables the assessment of farming systems which do not differ greatly (e.g. two types of integrated farming).

Possibilities of indication approaches basing on the population level are reviewed by Marc et al. (1999). Because prey consumption rates are said to depend on prey availability it is suggested that the quantity of potential prey is able to indicate habitat quality. Field data on food intake are related to body length, body weight, reproductive rate, metabolic rate and production of excreta. Nyfeller (1982) and Vollrath (1988) assessed different habitats by establishing a correlation between standard growth rates (of certain instars), calibrated in the laboratory, and field data from different habitats. From these correlations they drew conclusions on food consumption and the food supply under field conditions. Wise (1979) showed that an additional prey supply increases the egg production of orb-weaving spiders. However, Riechert and Tracy (1975) highlighted that a lower growth rate and finally reproduction rate are not intrinsically caused by a lack of food supply, but by (micro-)climatic factors: they demonstrated that compared to forest spiders, the food intake of open field spiders was reduced due to heat stress at noon, reducing feeding activity.

The structure and size of spider webs is also used as an indicator, particularly for pesticide effects (Retnakaran and Smith, 1980), but also indicates prey availability (Roush and Radabough, 1993; Riechert and Harp, 1987). Marc et al. (1999) collected data on the indication and accumulation of heavy metals such as $\mathrm{Cd}, \mathrm{Cu}, \mathrm{Zn}$ and $\mathrm{Pb}$ by spiders (e.g. Larsen et al., 1994): spiders accumulated $\mathrm{Cd}, \mathrm{Cu}, \mathrm{Zn}$ at higher levels than present in contaminated soils; epigaeic spiders to a larger extent than web spiders from the vegetation level. In agro-ecosystems, heavy metals 
occur in sewage sludge or are applied as pesticides $(\mathrm{Cu})$, particularly in organic farming (potatoes, grapes).

Büchs et al. (1997), Zimmermann and Büchs (1996, 1999) showed that rove beetles (Coleoptera: Staphylinidae) are suitable indicators to assess management intensity in arable crops and particularly insecticide input on the population as well as on the community. Parameters which displayed a clear positive correlation to increasing extensification were abundance (emergence from soil), "species density" (number of species per trap and sampling period) and change of dominance positions (Büchs et al., 2003). A cluster analysis (Büchs et al., 1997) proved to be the best tool to separate species communities of different levels of extensification. Also the phenology of single rove beetle species, for instance, is suitable for indicating disturbances due to management effects (e.g. insecticide input). However, it was demonstrated by Zimmermann and Büchs (1996) that due to the life cycle of rove beetle species, the effects of, for instance, insecticide applications only become apparent after a period of up to 9 months, so that survey periods should be scheduled for an appropriate length of time. Furthermore, it could be shown by Büchs et al. (unpublished) that most rove beetle species (and particularly Aleocharinae) leave their point of origin immediately after hatching, so that a survey with pitfall trap is not sufficient, but sampling has to be conducted essentially with emergence traps.

Bohac (1999) presents a complete system to indicate environmental stress on the basis of rove beetle species communities (including threshold values (in brackets)) which was validated by a comparison of data from several authors including the consideration of habitats with different anthropogenic influences. This assessment procedure considers: (a) percentage of eurotopic species (>90\%), (b) frequency of species with summer and winter activity of adult beetles ( $>20 \%$ summer activity), (c) proportion of winged species (no wingless specimens), (d) body size classes (more than 20\% "large" species), (e) preference to abiotic conditions as temperature and humidity (more than $70 \%$ thermoand/or hygrophilic species), (f) number of peaks in seasonal activity (less than two), (g) geographical distribution (wider than Europe), (h) number of life forms as zoo-, phyto-, myceto-, saprophagous or myrme- cophilic (less than 4), (i) sex ratio (>10\% from 1:1), and (j) a community index which separates rove beetle species into ecological groups according to their relation to undisturbed habitats such as climax forest stages, which per se cannot be achieved in agricultural ecosystems.

The suitability of ground beetles (Coleoptera: Carabidae) as indicators of the ecological status of arable fields is widely accepted and was shown, for instance, by Heydemann (1955), Topp (1989), Hingst et al. (1995), Schröter and Irmler (1999), Basedow (1990), Büchs et al. (1997) and Kromp (1999). Steinborn and Heydemann (1990) observed a tendency to a "homogenisation" of the carabid community of field habitats since 1952, a tendency which is stated by Blick (personal communication, 2002) for spiders. This homogenisation induced by crop management intensity, "hides" the influences of soil types on the field carabid community, which would naturally occur.

However, as shown by Perner (2003), habitat generalists usually have a lower coefficient of variance so that it is more favourable for them to achieve a "high level of precision" with a lower sample size. The habitat generalist Pterostichus melanarius (dominant in central European fields) is often said to be an indicator for intensive management, large field size and a degraded carabid species community (e.g. Müller, 1991; Raskin et al., 1992; Wallin, 1985). In contrast to these authors, Hokkanen and Holopainen (1986), Fan et al. (1993) and Büchs et al. (1999) recorded higher abundance with increasing extensification. These obviously contradictory results can be explained by the fact that $P$. melanarius larvae overwintering in the field are heavily affected by tillage, but due to the fact that a part of the population (adults) leaves the fields in autumn they rapidly recolonise the fields in spring so that larval mortality can be easily compensated for (Irmler, 2003). However, these facts show that due to this ambiguous and contradictory behaviour, the use of $P$. melanarius as an indicator is very critical and almost impossible, because no clear statements are correlated with an increase or decrease in abundance.

Döring and Kromp (2003) complain that already species numbers (of carabids) were suggested as indicators (Basedow et al., 1991; Steinborn and Heydemann, 1990; Kromp, 1990, Luka, 1996), but 
the mode of assessment of the indicator value and its reliability varies to a great extent. To enhance reliability Döring and Kromp (2003) pooled a lot of studies and analysed them on the basis of ecological species characteristics. Comparing organic versus conventional agriculture by an index based on the Wilcoxon matched pairs ranking (Hollander and Wolfe, 1973). Döring and Kromp (2003) created the "ecological type" as a key variable to distinguish between different environmental conditions caused by husbandry practice. The "ecological type" is defined by the abiotic and biotic demands of a species and the range which is tolerated. Referring to their index, carabid species with a high index value (as Carabus auratus, Acupalpus meridianus, Pseodophonus rufipes, Amara similata, A. familiaris, A. aenea, Poecilus versicolor) can be used as an indicator species for carabid biodiversity.

Also Büchs et al. (2003) identified C. auratus (Coleoptera: Carabidae) as one of the most suitable species indicating extensification combined with a high biodiversity, as did Steinborn and Heydemann (1990) for organic farming, whereas Irmler (2003) could not find a higher activity density in organic fields compared to conventional ones. Furthermore, Basedow (1998) and Büchs et al. (1999) showed that C. auratus indicates extensive cultivation by increasing activity density and body weight. Beyond that A. similata, A. aenea, A. familiaris, $P$. rufipes and Harpalus affinis benefit mostly from organic agriculture (Döring and Kromp, 2003) and so they can be assumed as the most important ground beetle species able to characterise low input agro-ecosystems.

Regarding the assessment of management intensity the following features of invertebrate species communities were generally observed (e.g. Döring and Kromp, 2003; Perner and Malt, 2003; Nickel and Hildebrandt, 2003) and seem appropriate as a basis for an indication: The more extensive management intensity was conducted:

- number and percentage of specialists increased, while generalists were reduced;

- diversity increased;

- high abundance is mostly caused by a low number of generalist species which are subject to extreme fluctuations; it/they indicate/s high frequency of disturbance and is/are thus related with intensification of management.

\section{Approaches for indication-critical survey and prospects}

Table 1 shows selected indicator approaches which are already established or to be tested in practice. Some of them are critically discussed in the following in order to provide an example.

\subsection{Direct indicators}

\subsection{1. $r$ - and $K$-selection as possible indicators for ecosystem assessment}

Undoubtfully $\mathrm{r}$ - and K-selection plays a role in the characterisation of agro-ecosystems with regard to management intensity (here: crop rotation). ${ }^{3} \mathrm{Re}-$ ferring to species communities, r- and K-selection seems to be one of the most important key issues for a biotic assessment of disturbance or environmental loads. Apparently r-strategist features can be related to a high, K-strategist features to a low level of management intensity, environmental loads or frequency of disturbance (Table 2).

Although r-/K-characteristics go back to a basic knowledge of animal ecology, check lists lack which classify species due to their gradual position on an imaginary scale, the $\mathrm{r}-\mathrm{K}$-continuum. This tool for the assessment of species communities and population features has only just recently been converted on the basis of reproduction biology for soil taxa as Gamasina (Ruf, 1998) and Nematoda (Bongers, 1990). Bongers (1990) introduced the "maturity index" (MI) for nematodes as a weighted mean of the coloniser-persistence $(\mathrm{c}-\mathrm{p})$ values for the non-plant feeding nematodes in a sample. If the species feeding on higher plants are to be included the use of the "plant parasitic index" (PPI) is proposed, which is negatively correlated; so that an increasing ratio of PPI/MI is identified as "ecosystem enrichment" (Yeates and Bongers, 1999).

The estimation of the gradual tendency of being an r- or K-strategist could, for example, be fitted into a scale between -1 (maximum r-strategy) and +1

\footnotetext{
${ }^{3}$ Related to microorganism communities the terms $\mathrm{r}$ - and $\mathrm{K}$-selection are used in a different way than in animal ecology: they are restricted to the concentration and limitation of the viability of a certain substance within the media which is inhabited, and growth rate $(\mathrm{r}=$ high concentration; no limitations of substance, high growth rate; $\mathrm{K}=$ low concentration, limited availability, low growth rate).
} 
Table 2

Simplified biological and ecological characteristics of $r$ - and K-strategists (r- and K-selection)

\begin{tabular}{|c|c|c|}
\hline Parameter & r-Strategists & K-strategists \\
\hline \multicolumn{3}{|l|}{ Reproduction } \\
\hline Reproduction period & $\begin{array}{l}\text { Semelparity (reproduction once in } \\
\text { lifetime) }\end{array}$ & $\begin{array}{l}\text { Iteroparity (repeated } \\
\text { reproduction periods) }\end{array}$ \\
\hline Season-related life-cycle of population & Polyvoltine & Univoltine \\
\hline Reproduction & $\begin{array}{l}\text { High reproduction rate (mass } \\
\text { production of eggs, larvae or } \\
\text { juveniles) }\end{array}$ & $\begin{array}{l}\text { Very low reproduction rate (only } \\
\text { single eggs, larvae, juveniles } \\
\text { with intensive, long period of } \\
\text { parental care }\end{array}$ \\
\hline \multicolumn{3}{|l|}{ Development } \\
\hline Growth, development, maturity & Fast & Slow \\
\hline Body size, body weight (in relation to taxocoenosis) & Small & Large \\
\hline Tendency to mutate & High & Low \\
\hline Lifetime & Short & Long \\
\hline Durable stages to survive uncomfortable conditions & Yes & No \\
\hline \multicolumn{3}{|l|}{ Population development/behaviour } \\
\hline Abundance & High & Low \\
\hline Population level & $\begin{array}{l}\text { High fluctuations within short } \\
\text { periods }\end{array}$ & $\begin{array}{l}\text { Constant level over longer } \\
\text { periods }\end{array}$ \\
\hline $\begin{array}{l}\text { Tolerance towards apocalyptic breakdown of } \\
\text { essential life conditions }\end{array}$ & High & Low \\
\hline Preferred concentration of habitat medium & High & Low \\
\hline \multicolumn{3}{|l|}{ Behavioural ecology } \\
\hline Tendency to migrate & High & Low \\
\hline Food & Mono-/oligophagous & Polyphagous \\
\hline Inter-/intraspecific competition & Low & High \\
\hline Building of territories & No & Yes \\
\hline \multicolumn{3}{|l|}{ Habitat ecology } \\
\hline Habitat characteristics & $\begin{array}{l}\text { Rapidly changing, subject to } \\
\text { stochastic disturbances }\end{array}$ & $\begin{array}{l}\text { Mostly stable, mature, changes } \\
\text { within regular intervals }\end{array}$ \\
\hline Habitat range & Eurytopic, ubiquitous & Stenotopic \\
\hline Range of biotic and abiotic habitat conditions & Euryoecious & Stenoecious \\
\hline \multicolumn{3}{|c|}{ Derived effects on species community and environmental conditions } \\
\hline Species diversity & Low & High \\
\hline Evenness & Low & High \\
\hline Frequency of disturbance & High & Low \\
\hline Management intensity & High & Low \\
\hline Environmental loads & High & Low \\
\hline
\end{tabular}

Data compiled by Bongers (1990), Ruf (1998), May (1980), Tembrock (1982), Schubert (1984), Stern and Tigerstedt (1974), Remmert (1984) and Odum (1980).

(maximum K-strategy) and the average of all species considered calculated. If the calculated value is above zero, the location is more $\mathrm{K}$-dominated, if below zero more r-dominated; the relevant conclusions and assessments can be made. Taxa with good knowledge on biological and ecological requirements of the species as, for instance, all vertebrates and ground beetles, Macrolepidoptera, spiders, Saltatoria, Auchenorrhyn- cha, Heteroptera, etc. should have the potential to be classified into the r-K-continuum, unless regional differences have to be considered (e.g. Kühnelt's principle of regional stenoecious behaviour; see Blower, 1955; Büchs, 1988). Unless good knowledge on ecological demands is possessed, the classification can be estimated as a permanent process and is subject to continuous changes with increasing scientific knowledge. 
Sampels (1986) used the ratio of zoophagous to phytophagous and saprophagous beetles in correlation with the body size mean of the on-site species community to determine the "degree of maturity" of vineyards with different management intensity in relation to adjacent semi-natural habitats. According to the habitat-template-hypothesis of Brown and Southwood (1987) biotic interactions are as, for instance, predator-prey relationships, negatively correlated with the degree of disturbance, which leads to the use of a predator-prey ratio as an indicator for environmental stress.

From the practical point of view it is more appropriate to concentrate monitoring on one or two species than on the whole species community (Döring et al., 2003). However, there was no correlation between carabid species richness and the abundance of a single species.

\subsubsection{Body size}

A decreasing average of body length at community level with increasing cultivation intensity is stated for several taxa (e.g. spiders, carabids, rove beetles) by Blake et al. (1994), Lorenz (1994), Büchs et al. (1997, 1999, 2003), but not by Döring and Kromp (2003), and-with regards to the population level—not by Büchs et al. (1999, 2003) either.

\subsubsection{Weight}

Van Vliet et al. (1995) conducted a comparative research on enchytraeids in forests and agricultural sites (tillage versus non-tillage in North Carolina, USA). Although population densities were greater in forest soils, in the arable soils the ash-free dry weight was nearly double that of forest soil. Based on the calculation that enchytraeid field soil turnover is $2180 \mathrm{~g} / \mathrm{m}^{2}$ per year, but only about $400 \mathrm{~g} / \mathrm{m}^{2}$ per year in forest soil, it can be assumed that enchytraeids have more influence on soil structure in arable fields than in forests, in spite of lower population densities. The ash-free dry weight and ash weight per enchytraeid was suggested as a key indicator for interpreting enchytraeid community structure to explain their functional role in ecosystems. More details regarding the suitability of body weight as an indication parameter are shown by Büchs et al. (2003).

\subsubsection{Taxonomic distance}

Warwick and Clarke (1998) propose weighting diversity indices by taxonomic distance (including phylogenetic information) as an indicator. According to their results taxonomic distinctness appears to be a more sensitive indicator of environmental perturbation than diversity indices which often remain constant over a perturbation gradient. From this point of view it can be assumed that an index like the taxonomic distinctness come closer to a 'biodiversity' index than $H_{\mathrm{s}}$. Furthermore, total genetic components of a biome may, within limits, remain constant but be partitioned differently among the hierarchy of taxonomic units according to the age of the succession stage of the assemblage. While biodiversity is heavily affected by the type of habitat, taxonomic distinctness depends more on trophic diversity which, however, is assumed to be strongly influenced by pollution. Therefore, Clarke and Warwick (1998) judge taxonomic distinctness as more suitable to indicate environmental stress than diversity indices (e.g. Shannon-diversity index $H_{\mathrm{s}}$ ).

Von Euler (Vancouver, Canada, personal communication, 2000*) believes that the "taxonomic distinctness" index meets most "biodiversity tool" requirements better then available alternatives because it relies on the average taxonomic path length between two species randomly selected from the recorded species set (Warwick and Clarke, 1998; Clarke and Warwick, 1998). Thus, the great advantage of this index is that it does not depend on sample size or the exact order of the samples and can also be applied across different studies with species lists that lack a clear sampling protocol. Therefore, it could be a major step to simplify assessments. However, developed and tested on the basis of marine nematodes up to date, this index was not applied to agriculturally used areas.

\subsubsection{Comparison of regional species pool to local species composition affected by management/disturbance}

A comparison of the regional species pool is another way of using species communities for biotic indication: surveying differently managed grasslands Nickel and Hildebrandt (2003) found a third of all species to be monophagous and $42 \%$ oligophagous. The comparison of the percentage of specialist feeding habits in local study sites (e.g. with different management 
intensities) with the regional potential number of these species allowed a very sensitive and gradual assessment.

\subsubsection{Species numbers, percentage of specialists and pioneer species}

Finally, species numbers, the percentage of specialists and pioneer species were identified by Nickel and Hildebrandt (2003) as suitable indicators of biotic conditions due to management intensity (in grassland ecosystems). The results of Büchs et al. (2003) for spiders and Döring and Kromp (2003) for carabid beetles led to similar conclusions: the percentage of habitat specialists and/or pioneer species was clearly correlated with management intensity of agricultural ecosystems. Curry (1987) has also pointed out that species numbers and the percentage of specialists and threatened species are negatively affected by increasing management intensity.

\subsubsection{Stenotopic field species}

Döring et al. (2003) and Döring and Kromp (2003) showed that ground beetles are supported by organic agriculture the more they are stenotopic field species. The enhancement of stenotopic field species as the most typical representatives for the habitat considered can be evaluated as a key criterion to evaluate the fauna of agro-ecosystems. Thus, the percentage of species specifically adopted to field conditions can be judged as a suitable indicator for an overall positive development of field habitat conditions.

\subsubsection{Relation of macropterous and brachypterous species}

Ground beetle species that profit to the highest extent from organic farming are usually xerophilic and tend to be macropterous (Döring and Kromp, 2003). The percentage of brachypterous carabid species was identified as an indicator for the "degree of maturity" by Gruschwitz (1981) and Rehfeldt (1984). However, Döring and Kromp (2003) state that stenotopic forest carabid species are mostly brachypterous and arewhen occurring in field ecosystems-enhanced by conventional cultivation (due to microclimatic conditions because of a higher density of the vegetation). Thus, with respect to the fact that organic cultivation promotes stenotopic field species more than conventional agriculture, brachyptery cannot be used as an indicator for a status of field habitat conditions which are regarded as sustainable.

\subsubsection{Invertebrate species communities related to "Ellenberg"-indicator values}

According to Perner and Malt (2003) soil humidity is most suitable as a model parameter for a biodiversity assessment on the landscape level, particularly when meadows or floodplain areas are assessed. Even the indicator value for humidity developed by Ellenberg et al. (1992) (see also Hill et al., 1999) for vascular plants has quite a similar potential as an indicator but leads to less clear statements. The indicator values of Ellenberg et al. (1992) were successfully correlated to species assemblages of beetles out of pitfall trap samples when plant communities in the catchment area of each trap were surveyed at the same time (Stumpf, personal communication, 1996).

\subsubsection{Correlation of plant and animal assemblages}

According to Döring et al. (2003) there is a lot of evidence of a correlation between species diversity of plants and zoological taxa (Weiss and Nentwig, 1992; Zanger et al., 1994; Denys, 1997). Among carabids, omnivorous groups as, for example, Harpalinae and Zabrinae, profit mostly from a higher species richness of plants. However, a positive correlation of weed cover to species richness of carabid beetles is restricted by the fact that a higher weed density results in a higher "spatial resistance" ("Raumwiderstand"; e.g. Heydemann, 1955) that hinders carabids moving around. Pfiffner et al. (2000) showed by multivariate data-analysis that site characteristics such as plant diversity and the type of habitat can significantly influence the ground beetle fauna. This attempt is extended to flower visiting insects and other animal taxa by Kratochwil and Schwabe (2001).

The correlation of plant species richness to carabid biodiversity includes all types of habitat preferences. This allows independence regarding methods used for ecological assessment in relation to the choice of goal parameters. From these findings it could be concluded that plant species richness can potentially be used as a surrogate measure for faunistic species diversity at least for carabids. However, Döring et al. (2003) point out that weed diversity might be suitable for a rapid assessment of faunistic biodiversity, but is alone not sufficient for a more sensitive measurement (e.g. by 
using highly specialised carabid species as indicators), particularly if mainly conventionally managed fields (between which the differences of management intensity are more subtle) have to be evaluated, as is the usual practice. Therefore, besides plant species richness, Döring et al. (2003) used three more parameters (activity density, activity density of single carabid species and percentage of weed cover) as indicators for carabid species richness.

\subsection{Surrogate indicators}

\subsubsection{Soil quality index ("Bodenpunktzahlen")}

Brose (2003) tested a correlation between soil quality index and carabid species diversity: the lower the soil quality index was the more ground beetle species could be recorded. Some results from other authors (e.g. Irmler, 2003; Büchs et al., 1997; Harenberg, 1997) support this hypothesis. In particular Irmler (2003) and Perner and Malt (2003) showed a correlation between sand content of soil and carabid and spider species richness. Steinborn and Meyer (1994) identified soil type as the most important influencing factor affecting the carabid species community followed by crop type and management intensity. Within this ranking, the effects of cultivation techniques were stronger on loamy soils compared to sandy soils. Also for plant communities, similar relations can be assumed (e.g. Mattheis and Otte, 1994; Wicke, 1998). However, the best parameter to explain the variances is "temperature" for spiders and "soil humidity" for beetles (Perner and Malt, 2003). Sandy soils usually achieve a low soil quality index. With the precondition that a mapping of soil quality is available this indicator, which is easy to apply, has the potential for a rapid classification of agriculturally used landscapes on higher scale levels, for instance, within planning procedures or to define areas which are designed for particular environmental programmes.

However, as a factor mainly caused by natural conditions the soil index is almost independent of management intensity, so it has no educational component and will not lead farmers to change and improve their husbandry practice towards sustainability. Finally, large areas in central Europe with high yielding soils (e.g. loess soil) will again be virtually excluded from environmental programmes and approaches as they are already today. So, beyond special environmental pro- grammes, for any subsidisation of the ecological performance of management practices, farmland should be classified into two or three classes depending on the soil quality and should be monitored and assessed separately by applying different goal criteria and thresholds of success (of an ecologically motivated crop production) as in environmental programmes.

\subsubsection{Length and quality of field margins}

Due to results of Wallin (1985), Gilgenberg (1986), Basedow (1988), Dennis and Fry (1992), Kinnunen et al. (1996), Pfiffner and Luka (1996) and Irmler (2003) it can be assumed that length and quality of field margins (uncultivated habitats adjacent to fields) influence the field fauna significantly. Length and quality of field margins is proposed by Waldhardt and Otte (2003) as an indicator for biodiversity from a botanical point of view.

\subsubsection{Organic farming as a surrogate indicator}

Döring et al. (2003) and Döring and Kromp (2003) showed that ground beetles in organic fields produce a higher diversity of stenotopic species (most of them xerophilic and typical for (sandy) field habitats) compared to conventionally managed fields. Furthermore, herbivorous species are enhanced due to the more diverse and dense weed cover. Conventional farming, however, promoted mainly populations of euryoecious and ubiquitous species and of some hygrophilous forest species due to a more dense crop plant cover. Considering other studies on this subject the supraregional validity of these indicators could be shown by Döring and Kromp (2003).

Compared to conventional crop management $34 \%$ more ground beetle species in organic fields were recorded. Within a survey of 58 fields Irmler (2003) recorded more species only in fields which had been managed organically in the long term (at least 30 years), but not in those that had only been managed organically for a short period. However, no ground beetle species predominated especially on organic fields. The differences in ground beetle composition in organic fields compared to conventional farming (e.g. Pfiffner and Luka, 1996, 1999; Pfiffner and Niggli, 1996; Hokkanen and Holopainen, 1986; Basedow, 1990; Raskin et al., 1992) are attributed to the higher abundance of prey items and lower pesticide input in extensively managed fields. 
With regard to plant communities, in conventional agriculture mainly nitrophilous and ubiquitous pest weeds are enhanced. Plant communities of organic fields were "more complete" with a higher percentage of dicotyledons, and so a prolonged period with flowering plants and a gradual transition of plant communities, zonation types and reduction species numbers was observed from the field edge to the centre of the field, while in the conventional farming systems these changes occurred abruptly (Döring et al., 2003). Positive effects of weed communities on the abundance and biodiversity of beneficials (particularly parasitoids) have been highlighted by Altieri (1999). From these results it can be concluded that the specific features in species composition in organic farming systems also indicate functional consequences.

This raises the question of whether organic agriculture itself can be used as a(n) (indirect) surrogate indicator for matters of biodiversity and/or sustainable agriculture or whether adaptations have to be considered which potentially compensate for the differences in the species composition of organic and conventional farming systems or even complement them, so that - in order to provide a maximum biodiversityboth systems (i.e. conventional and organic) have their advantages.

Arguments for the installation of organic farming as a surrogate indicator to maintain biodiversity are as follows:

- The philosophy of organic farming is fundamentally oriented around the consideration of natural processes and cycles as basic elements of a sustainable manner of farming (e.g. http://www.ifoam.org).

- Organic farming is restricted to clear and fixed regulations stated by EU Regulation 2092/91 and $473 / 2002$ (EU-Commission, 1991, 2002) or by the growers associations (e.g. Demeter, Bioland, etc.) which can be controlled easily (a control system is already well established), in contrast to other farming systems as, for instance, "integrated farming".

- Several studies show for a lot of taxa (e.g. ground beetles, birds, mammals, butterflies) that organic farming definitely enhances species numbers and biodiversity for animals as well as for plants (The Soil Association, 2000; Van Elsen, 1996, 2000; Frieben, 1997, 1998; Kromp, 1990; Döring and Kromp, 2003; Pfiffner, 1997; Pfiffner and Luka,
1999; Pfiffner and Mäder, 1997; Pfiffner and Niggli, 1996; Rösler and Weins, 1997).

Objections to using organic farming as a surrogate indicator for sustainable production are, for example:

- the use of substances containing copper, such as fungicides in potatoes and vineyards. Copper is obviously transferred to the food-chain (Wittasek, 1987; Rhee, 1997; Hopkin et al., 1986, Paoletti et al., 1988) and may affect animal biodiversity;

- intensive tillage systems due to mechanical weed control;

- a high percentage of summer crops with soil tillage in spring which affects soil-dwelling arthropods and their biodiversity negatively as shown clearly by Büchs et al. (1999).

Furthermore, differences between conventional and organic agriculture are gradual, that means there are "overlapping areas" regarding the ecological performance of both systems. In particular, a tendency to increase management intensity is observed, even in organic farming (Döring, 2000, in litteris). Döring et al. (2003) estimate organic farming as a high contribution to nature protection, but believe that it is alone not sufficient as an indicator for biodiversity.

\subsubsection{Biodiversity indicators at landscape level with reference to habitat features}

Indicators related to landscape issues should have the potential to be regionalised, but at the same time be suitable for blanket coverage assessments for supraregional planning. Furthermore, rules have to be defined for bottom-up assessments (conversion from a particular spot to a region).

Approaches concerning the development of a "landscape diversity index" which are founded on the hypothesis that the basic potential of the biodiversity of any location (and so of the landscape itself) depends on the diversity of land use types (and other habitats) in a defined area around the location considered. The aim of these approaches is a comparative evaluation of land use patterns to predict the effects of hypothetical land use changes using a model. They often deal with indicator species (assemblages) whose habitat requirements are considered in relation to landscape analysis. Areas with concentrations and deficiencies with respect to these habitat requirements 
are identified (Hawkins and Selman, 1994). Such integrated studies of patches within their surrounding land use matrix have been developed in several variations for animals (e.g. ants, beetles, birds), as well as for plants, e.g. by Dauber et al. (2003), Waldhardt and Otte (2003), Steiner and Köhler (2003) and Hirsch et al. (2003). A precondition for such an assessment is to allocate a certain value to each land use and habitat type. However, this procedure is based unavoidably to a certain extent on subjective decisions. The suitability of a modified Shannon-diversity index on the basis of taxon-related species numbers/species compositions for each land use (and habitat) type which are identified as reference values is tested (Dauber and Gießen, personal communication, 2000).

This raises the question of specific reference values for regions and/or natural units: Which target value should a "landscape diversity index" achieve in landscapes of different types and characters? Furthermore, what are the criteria to define reference values, target values and the surveyed area (circle radius) which is related to the location that should be assessed with regard to the taxon considered? Examples from a survey on "Ecological Priority Areas" in Switzerland by Jeanneret et al. (2003) show that:
- For the presence of butterflies in cultivated areas the performance of adjacent habitats is of great importance. This means that the attainability of these undisturbed areas plays a major role in the biodiversity of butterflies.

- For the presence of spiders, however (which colonise any location with considerable numbers by ballooning), the performance of adjacent habitats is less important than the diversity and spatial structure of the species community of plants (within and adjacent to the field) and the performance of husbandry practices.

\section{Development of biotic agri-environmental indicators-fundamental problems}

The most outstanding fundamental problems within the development of biotic agri-environmental indicators are summarised in Table 3. A selection of key issues is discussed here. The problems listed in Table 3 are multiplied by the fact that in agricultural landscapes, a focus on one or a few impact factors is not possible, but pesticides, harvest, tillage, mineral fertilisation, crop rotation, etc. are present in varying

Table 3

Problems of development and application of biotic indicators for biodiversity in agro-ecosystems

Studies on reference values and limits are lacking or can be determined only with efforts that are not feasible

Fixing of baseline references (e.g. species richness: for central Europe 1850 as year of reference defensible?)

Availability of suitable data

Sample size required often not feasible

Efforts for data survey too high even if restricted to a minimum set of data $\Rightarrow$ a blanket coverage of indicator use is not possible

A high degree of uncertainty of statements has to be tolerated

Lacking standardisation of methods for data surveys and assessments

Weighing of indicators in complex assessment procedures $\Rightarrow$ establishment of priorities

"Overlapping" of indicators (with regards the area covered) $\Rightarrow$ risk of double assessments

Reference to spatial scale level

Need for regionalisation of indicators

Understanding and interpretation of the term "biodiversity"

Lack of models sufficiently adopted to demands of practice

Discrepancies between global requirements on international levels and the degree of sensivity and power for detailed statements on the ecosystem level

Efforts of attendant monitoring programmes

Basic requirements (possibility of standardisation, repeatability, unambiguous interpretation) not always fulfilled

Repetition of indicator surveys (frequency/time period)

Dealing with assessment errors and limitations due to bottom-up scaling and data-aggregation

Communication between pure research, applied research, institutions responsible for conversion into practice, political decision makers and users 
performances depending on the type of husbandry practice (Paoletti, 1999a,b).

\subsection{Development of baseline reference values}

Data surveying and determining baseline reference values is one of the major problems particularly within field assessments and most serious for animal populations due to their high mobility, migrations between different habitats and changes in population density from season to season. Due to the fact that each location has its specific, almost individual (abiotic) conditions (e.g. (micro-)climate, soil type, (ground) water supply, exposition, habitat size, surroundings, vegetation structure, etc.) it is nearly impossible to draw general conclusions: each field trial has to be judged more or less as a unique "case study". Nevertheless, the elaboration of baseline reference values is theoretically possible (e.g. for species numbers by comparison of a regional special pool to the local species composition; see above). It does, however, require a tremendous amount of work to fulfil demands on statistical significance, which is usually not feasible. A way out of this problem is to relate results to a standard (control) treatment with fixed conditions (e.g. Bartels and Kampmann, 1994; Steinmann and Gerowitt, 2000; Holland et al., 1994). However, to derive general reference values, the features of a standard used as a reference and the goal criteria to be achieved have to be defined clearly and agreed on generally (i.e. supraregionally). This is usually not the case; each approach creates its own standard, meaning in the end that the standards are not comparable.

The standardisation of survey methods is essentially linked with these aspects. For invertebrates Duelli and Obrist (2003) recommend Berlese soil extractors for endogaeic taxa, pitfall traps for epigaeic arthropods and window flight traps for insects flying above the vegetation level. They prefer plots and transects as measures for recording biodiversity related to certain taxa.

\subsection{Required sample size and quality of indication}

Sample size influences essentially the quality of indication, thus, it is one of the most critical aspects with regard to the chances of putting biotic indicators into practice.

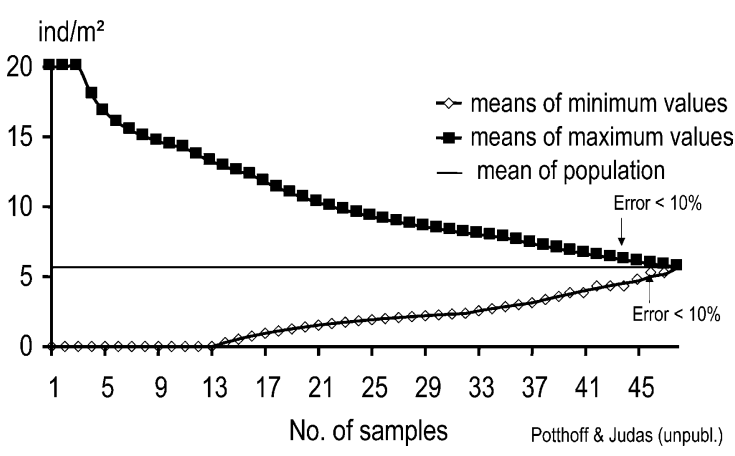

Fig. 1. Required sample size in relation to maximum possible error: means of $L$. terrestris abundance depending on the number of samples (Potthof and Judas, unpublished).

This issue which is particularly neglected in scientific attempts can often be demonstrated, for example, by an experiment by Potthoff and Judas (unpublished): on a forest soil plot of $12 \mathrm{~m}^{2}$ a complete survey of the abundance of Lumbricus terrestris L. earthworms was conducted. The total of all 48 samples of $0.25 \mathrm{~m}^{2}$ showed an abundance (area-related density) of $5.7 \mathrm{ind} / \mathrm{m}^{2}$ on average. Fig. 1 shows the mean of L. terrestris abundance related to the sample size. The mean of $n$ samples with the highest abundance was compared to $n$ samples with the lowest abundance. It could be demonstrated that only if more than $90 \%$ of all potentially possible samples were taken (44 samples out of a total of 46 total samples) the maximum possible error was below $10 \%$.

Financial means always limit personnel and temporal possibilities so that an appropriate balance has to be found between time-consuming field sampling, species identification, data processing and the skills expected from those who conduct the data surveys (Perner, 2003).

Perner (2003) created the "Level of Precision" (LOP) defined as the number of samples required to achieve a tolerable variance with regard to data. The definition of an LOP is quite reasonable because a precondition for the successful application of an indicator, particularly in agro-ecosystems, is that differences at species or species community level are detectable, regardless of a considerable "data noise" (mean variation) within the same farming system. This is of major importance because in practice, a comparison of extremely different farming systems is 
not usually made (e.g. between organic and conventional farming), but within conventional farming.

Summarising, Perner (2003) developed the following basic principles:

- Habitat generalists achieve a better LOP with a smaller sample size than habitat specialists (e.g. for a number of 10 samples the LOP for the generalist carabid species $P$. melanarius is $25 \%$, for $\mathrm{Bem}$ bidion obtusum $50 \%$, but only $60-100 \%$ for habitat specialists as, for instance, Calathus erratus).

- Species communities should be preferred as indicators to indicators which rely on one species: to achieve the same LOP for a single species a higher number of samples has to be taken compared to species communities.

- Among community parameters, evenness is particularly recommended for biotic indication: Perner and Malt (2003) demonstrated for different kinds of grassland management that evenness is precise enough to distinguish between apparently rather similar management strategies.

- The required sample size varies greatly, up to a manifold of the original size: (a) from year to year (season to season), (b) from habitat to habitat, and (c) from taxon to taxon, with the consequence that in many cases differences cannot be stated as significant although they in fact occur.

- With regard to taxon, ground beetles (Coleoptera: Carabidae) require a larger sample size (pitfall traps) than spiders (Arachnida: Araneae) or Coleoptera in general to achieve the same LOP in order to assess species richness and evenness. A rather surprising result which contrasts sharply with common practice, because among field-inhabiting invertebrates, carabids are favoured as one of the easiest indicator taxons to assess.

\subsection{Selection of taxa for biodiversity assessments}

As mentioned above biodiversity in its entirety can never be recorded and assessed: Riecken (1992) showed that in biodiversity assessments within legally established planning procedures in Germany only a very restricted set of taxa was considered with a high risk of incorrect assessments as a consequence: overall, less than $50 \%$ of environmental assessment
Table 4

Consideration of zoological taxa in environmental assessment procedures within legally established planning procedures (Riecken, 1992, 1997)

\begin{tabular}{ll}
\hline Taxon & $\begin{array}{l}\text { Percentage in environmental } \\
\text { assessments }\end{array}$ \\
\hline Birds & 95 \\
Amphibians/reptiles & 48 \\
Mammals & 30 \\
Butterflies & 27 \\
Dragonflies & 25 \\
Snails & 14 \\
Grass-hoppers & 11 \\
Ground beetles & 9 \\
Other beetles & 5 \\
Bugs & 5 \\
Spiders & 5 \\
Leafhoppers & 2 \\
\hline
\end{tabular}

procedures considered zoological aspects at all, 34\% of these considered only one taxon, $50 \%$ up to five and only $16 \%$ more than six and more taxonomical units (Table 4).

Regarding the practice of data surveys within repeated applications of bioindicators by $\mathrm{McGeoch}$ (1998) and Riecken (1992) plants and perhaps also vertebrate taxa such as birds are frequently used as indicators; however, invertebrate taxa are mostly neglected, although it is well known that invertebrate communities form the major part of biodiversity in every ecosystem and have the potential to indicate environmental stress and gradual changes (Büchs, 1995; Majer and Nichols, 1998; Wheater et al., 2000; Andersen et al., 2001).

\subsection{Mutual neutralisation of indicators}

A serious problem is that different indicators potentially neutralise themselves in producing opposite results particularly when used to indicate the success of certain measures applied. Different requirements of birds which nest in hedgerows and those which breed in open landscapes can be brought in as an example: while hedgerow breeders are enhanced by planting and maintaining hedgerows, the population density of open land birds is reduced and vice versa (Hoffmann and Greef, 2003). This phenomenon can be converted to all other taxons in principal (e.g. carabids, spiders, rove beetles, butterflies, etc.). 
In this context, Hoffmann and Greef (2003) and Hoffmann et al. (2003) developed a kind of "mosaic indicator approach". The qualitative and quantitative assessment takes place under consideration of the historical development of the landscape. For the focus on "species" features, birds and flowering plants were selected, for the focus on "habitat" features, uncultivated areas (e.g. hedgerows, field margins, etc.) as well as areas within field locations with extreme conditions such as wetlands or arid spots (Brose, 2003; Richter et al., 1999) were considered.

\subsection{Simplification of indication approaches}

Studies on the basis of indicators must be technically simple and easily repeatable by different people with different levels of skill in different situations (Paoletti, 1999a,b). The main reason for assessing a facet of biodiversity with the help of an indicator, instead of measuring that target directly, is higher efficiency. Therefore, one needs to show that the loss of precision and accuracy is compensated for by gaining time and money. Because biodiversity in each facet is a moving target in time and space, indicators will need recurrent calibration. If a gain in efficiency cannot be convincingly shown because the precision and accuracy of the indicator cannot be established, then that "indicator" is not appropriate for the purpose intended. These principle thoughts of Von Euler (Vancouver, Canada, personal communication, 2000*) implicate a significant simplification of indicators, and of related assessment and survey methods. Using simplified methods (indicator systems), a considerable error probability and somewhat less clear statements have to be taken into account.

Generally, environmental monitoring programmes avoid the recording of invertebrates because of the high expenditure and costs (World Bank, 1998). Derived from Foissner's (1999) statements for Protozoa some key issues are listed which in principal can be transferred to most invertebrate in general:

- large number of species;

- costs, labour and high level of skill needed for identification;

- simple and/or computerised keys are lacking;

- time-consuming counting of abundance;
- as a contrast, for instance, to dragonflies or butterflies most invertebrate taxa are not attractive for the public and most researchers;

- unaffordable number of samples required to fulfil demands for statistical significance.

For a rational biodiversity assessment of arthropods, several procedures are suggested (Duelli and Obrist, 2003; Cranston and Hillman, 1992; Oliver and Beattie, 1996):

- To restrict sampling to a low number of taxa over a long period.

- To conduct sampling of a great range of taxa over a short period of time.

- Rapid biodiversity assessment: evaluates the number of taxa by using samples over a couple of weeks recorded with a standardised set of sampling methods, considering the whole taxonomic range but only on the basis of morphospecies.

- Sampling is not restricted to taxonomic units but to a sampling method. The more taxa a method is able to record, the higher the chance is for assessing a representative taxonomic range of the entire fauna of an ecosystem.

Therefore, Duelli and Obrist (2003) favour a reduction to an "optimised" selection of taxa for biodiversity assessments. Their concept includes a two-step approach that allows the use of all kinds of indicators with regard to their correlation to biodiversity. The best correlation was achieved by bugs and bees. It was shown that a reduction of the sampling period to five selected weeks by exceeding the number of taxa resulted in correlations which were nearly as good as those demonstrated for bugs and bees. If linear correlations of indicators to biodiversity are not focused on taxonomic units, but extended to a selected sampling method, the advantage is that the taxonomic range included in the assessment is widened. And so the chance increases of a better correlation to or representation of the entire species set of the ecosystem compartment assessed.

Simplified indication methods based on morphospecies carry the risk that a lot of species will be overlooked if taxonomically more ambitious taxa are included in the assessment (e.g. Auchenorrhyncha, Linyphiid-spiders, Diptera families like Anthomyiidae, Cecidomyiidae, Sciaridae, Coleoptera 
(sub)families like Aleocharinae, Cryptophagidae, Curculionidae or parasitic Hymenptera, etc.). Such a procedure might be possible for assessing ecosystems with intrinsically different features (e.g. hedgerows and fields), but in the case of comparing cultivated areas itself, whose species diversity differs only slightly (e.g. different kinds of conventionally used fields), an index based on morphospecies will be too uncertain to detect differences with the sensitivity and exactness needed and so, might fail.

In most of the many assessment procedures used currently, surrogate measures are usually used as indicators, for instance, percentages of uncultivated areas, the length of hedgerows or field margins, crop diversity, etc. (e.g. Braband et al., 2003; Menge, 2003). Demands for a simplification of methods for biodiversity assessments in land use systems are so extreme, that it can be assumed that in the end-regardless of all limitations - only surrogate indicators such as mentioned above seem to have a real chance of being applied in practice, as is already usual today (see Braband et al., 2003). Duelli and Obrist (2003) stress the fact that the use of surrogates is only possible after the conservation value has been established; they state also the lack of empirical data to test such indicators.

However, with regard to other ecosystem types of economical importance biotic indicators based on taxonomic work are not unusual at all: the evaluation of the water quality of freshwater ecosystems is highly standardised by the "Saprobien index" (whose origin can be traced back to nearly a 100 years ago). This index is applied regularly on an international scale, and is continuously developed (Friedrich, 1990; Marten and Reusch, 1992; Usseglio-Polatera et al., 2000). For freshwater habitats (or riparian habitats with contact to freshwater habitats) a status of assessments has already been achieved which is far beyond our status of the assessment of land use practices in terrestrial habitats (Innis et al., 2000):

- methods which have already shown their benefits in practice are regularly updated and cross-calibrated;

- new rapid assessment methods are in development that provide reasonable levels of accuracy for a variety of users in a variety of situations;

- assessments are currently developed for special applications with selected users;
- the degree of uncertainty is explicitly reported;

- implications of specific assessment methods on political decision making is openly addressed;

- the methods are formally tested for accuracy, cost effectiveness and practicability;

- Innis et al. (2000) show ways how to transfer models used for freshwater assessments to (semi-)terrestrial habitats.

\section{Biodiversity assessment-do we know our goals and the effects of the measures we take?}

The introductory phrases on the use of the term "biodiversity" shall elucidate how complex, difficult and misleading its use and, moreover, assessment procedures are, especially for agricultural ecosystems.

"Biodiversity assessment" means more than "biodiversity measurement". Biodiversity is essentially measured for a particular purpose. Biodiversity assessment is the analysis of differences between a present state and a reference one. Whatever this "reference state" may be depends on the purpose of the biodiversity assessment (Watt, Banchory, Scottland, UK, personal communication, 2000*).

It is well known (Odum, 1980) that if arable land is left to natural succession, the species diversity increases until a certain stage of succession (usually stages with shrubs and/or singles trees, that contain so to speak "a little of everything") is achieved. Only at the forest stage, as the final climax stage, does biodiversity decrease again, and is at its lowest inside of the forest ecosystem.

The year 1850 is rather often suggested as a kind of "reference year" that represents the peak of biodiversity in central Europe (Bick, 1982; Piorr, 2003). At that time the ideal of patchy and highly structured rural landscapes in central Europe occurred during conditions of subsistence and was accompanied by poverty and starvation (Konold, 1996). Derived from this knowledge, today the maximum increase of (structural) diversity and of the percentage of secondary components (e.g. landscape elements, land use types, habitat types) and of uncultivated areas is regarded as a "guarantee" for the development of a high level of biocoenotic biodiversity. In the sense described above, many models and recommendations in central Europe exist as, for instance: 
- to reduce the field size (Knauer, 1993);

- to develop so called "habitat connective systems" ("Biotopverbundsysteme"), that means to increase the percentage of uncultivated areas at the field edge like field margins, tree rows, hedgerows, adjacent ditches (Jedicke, 1994; Steidl and Ringler, 1997);

- to introduce artificially sown weed strips into larger fields (Nentwig, 2000).

The endeavours to enhance the biodiversity of cultivated areas by introducing structural elements could be managed (and controlled) easily by agricultural/environmental administrations; it developed into one of the most popular measures and was integrated into several assessment procedures for evaluating the environmental impact of a farm or its husbandry practice (Braband et al., 2003). Such areas are called Ecological Priority Areas (EPAs) and are surrogate indicators of biodiversity, of which a minimum percentage of agricultural landscape is fixed (e.g. Roth and Schwabe, 2003), perhaps complemented by an index, that describes the diversity of habitat types, their dispersal and juxtaposition, and the edge density as it is proposed by the EU-Commission (Eiden et al., 2001a,b; Willems et al., 2001; Gallego et al., 2001; Steenmans and Pingborg, 2001).

This kind of action and these aims are quite understandable with regard to the intensification of crop management in central Europe, which began in the 1970s with a high increase in nitrogen and pesticide input combined with the creation of a landscape type (mostly during procedures within the reparcelling of land) whose first priority was to fulfil the technical demands for a maximum-yield-crop-production. However, there is a need for differentiation. Problems of such a "linear" understanding of biodiversity matters as well as the difficulty in selecting single species, structures or ecosystem components as representatives (indicators) for a high or low biodiversity shall be demonstrated in the following examples.

\subsection{Contradiction of island-theory and mosaic-concept}

According to the conclusions derived from the research on island ecology (Macarthur and Wilson, 1967) species richness increases together with an increase in the size of the area of the habitat type

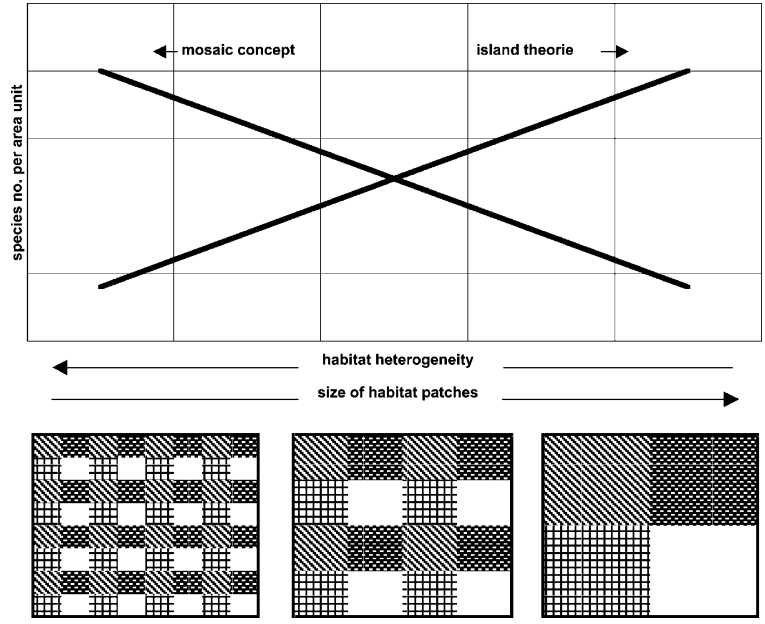

Fig. 2. Simplified model scheme to explain contradictory effects of island-theory (McArthur and Wilson, 1967) and mosaic-concept (Duelli, 1992): an increasing habitat size coincides with a decreasing habitat diversity (Duelli, 1992; see also Jedicke, 1994).

considered. However, following the mosaic-concept of Duelli (1997) species richness increases the more habitat types there are and the more heterogeneous habitat types are present in a defined area. According to the theoretical model, effects of the island-theory and mosaic-concept neutralise each other (see scheme in Fig. 2). In reality this model functions not as strictly as shown because of the exchange of species between different habitats (Duelli, 1992), but for a defined area it is clear: the larger each single habitat type becomes, the lower the number of different habitat types will be. Furthermore, the "quality" of species (euryoecious species versus stenoecious species) has to be considered: without any doubt an increase of species diversity will be recorded by an increasing percentage of structural elements in rural landscapes. However, most probably, habitat types which are introduced additionally, but are relatively small in size, are usually inhabited by different, but very common species in not very abundant populations, while stenoecious species in populations with a reasonable chance to survive occur only in considerable abundance if a threshold size of each habitat type is achieved (e.g. Kareiva, 1987; Kruess and Tscharntke, 1994).

Contradictory to the mosaic-concept (Hansson et al., 1995; Duelli, 1992) Brose (2003) could not show an effect of the landscape features (e.g. heterogeneity) on the regional species biodiversity of carabids in 
temporary wetlands within fields, except the density itself of these wetland patches. Jeanneret et al. (2003) showed a dependence on the taxon considered: whereas in agriculturally used landscapes butterflies (Lepidoptera: Rhopalocera) are heavily influenced by the landscape structures adjacent to fields and the landscape matrix in general, the effect of structural components is less important for spiders and obviously other epigaeic (and endogaeic) arthropods.

\subsection{Regions with a historically verified low percentage of landscape structures and large field size}

In central Europe there are several regions (e.g. Sachsen-Anhalt, Schleswig-Holstein, Bavaria, central and north Poland, Hungarian Puszta, Austrian eastern Burgenland) that present large fields and a landscape poorly equipped with structural elements since the beginning of the 19th century. For instance, in some regions of Schleswig-Holstein, owned and managed by landlords, field plots of about 20 ha were completely normal as early as 300 years ago (Becker, 1998). Endeavours to increase biodiversity by introducing landscape elements would conflict with the historically grown type of landscape in this region (Fig. 3).

In central Europe recent field size and structural diversity (in a spatial sense) is strongly influenced by topographical conditions and the line of succession (e.g. "Realteilung", "Anerbenteilung", "Stockerbenteilung"). Such socio-economically regional differences and their impacts on biodiversity are considered, for example, within the concept of Roth and Schwabe (2003), where the goal criterion percentage of Ecological Priority Areas is also determined by historical developments: while the goal percentage in an area that is traditionally intensively used for agricultural production is fixed at a level of $10 \%$, in a "Realteilungsgebiet" (very small fields due to equal portioning of inheritance) that is situated in a mountainous area with poor soils a goal percentage of Ecological Priority Areas of 23\% was determined.

\subsection{Examples of high diversity levels and habitat-related species communities on large-sized fields}

After the reunion of Germany there was an intensive discussion on the faunistic importance of large-sized fields (>20 ha), which are more common in eastern Germany, versus small-sized fields (Wetzel, 1993; Poehling et al., 1994) with regard to biodiversity and field-typical expressions of zoocoenosis. In spite of all objections, recent investigations stated: on large-sized fields in eastern Germany (Wetzel, 1993; Wetzel et al., 1997; Volkmar and Wetzel, 1998; Kreuter, 2000; Hoffmann and Kretschmer, 2001; Richter et al., 1999; Stachow et al., 2001; Brose, 2003) and Hungary (Basedow et al., 1999) comparatively high species numbers and a high percentage of endangered species were recorded for several taxa. Furthermore, on large fields in agriculturally used landscapes almost completely cleared of structural elements, specialist species occurred among carabid species that were not recorded in nearby smaller fields in patchy, well structured landscapes (Table 5; Kreuter, 2000). Most of the species recorded in the centre of large fields are xerothermophilic, so that the species composition obviously shows special adaptations to the regional climatic conditions. The climate in eastern parts of central Europe (e.g. eastern Germany, Poland, Czech Republic, eastern parts of Austria and Hungary) is far more continental than in western parts (e.g. western Germany, northern parts of Switzerland, eastern parts of France and Benelux) and, therefore, the fauna contains more elements that are adopted to eastern "steppe"-conditions. These "steppe"-elements obviously meet with suitable conditions particularly within large fields in continental climates. Furthermore, the structure of these large fields develops considerably within field differences with regards, for example, to soil type, seed density, relief, exposure and soil humidity which results in a great variability of microhabitats and microclimatic conditions (Richter et al., 1999; Brose, 2003).

\subsection{Examples of high levels of biodiversity in rural landscapes with a large extent of human impact}

The reparcelling in the Kaiserstuhl area, a vinegrowing area in south-west Germany, at the end of the 1970s, resulted in a significant reduction of the number of vineyard terraces and embankments. The resulting landscape gave the region its title of "lunar landscape", compared to the tiny structure of the old vineyards (Fig. 4a and b). 

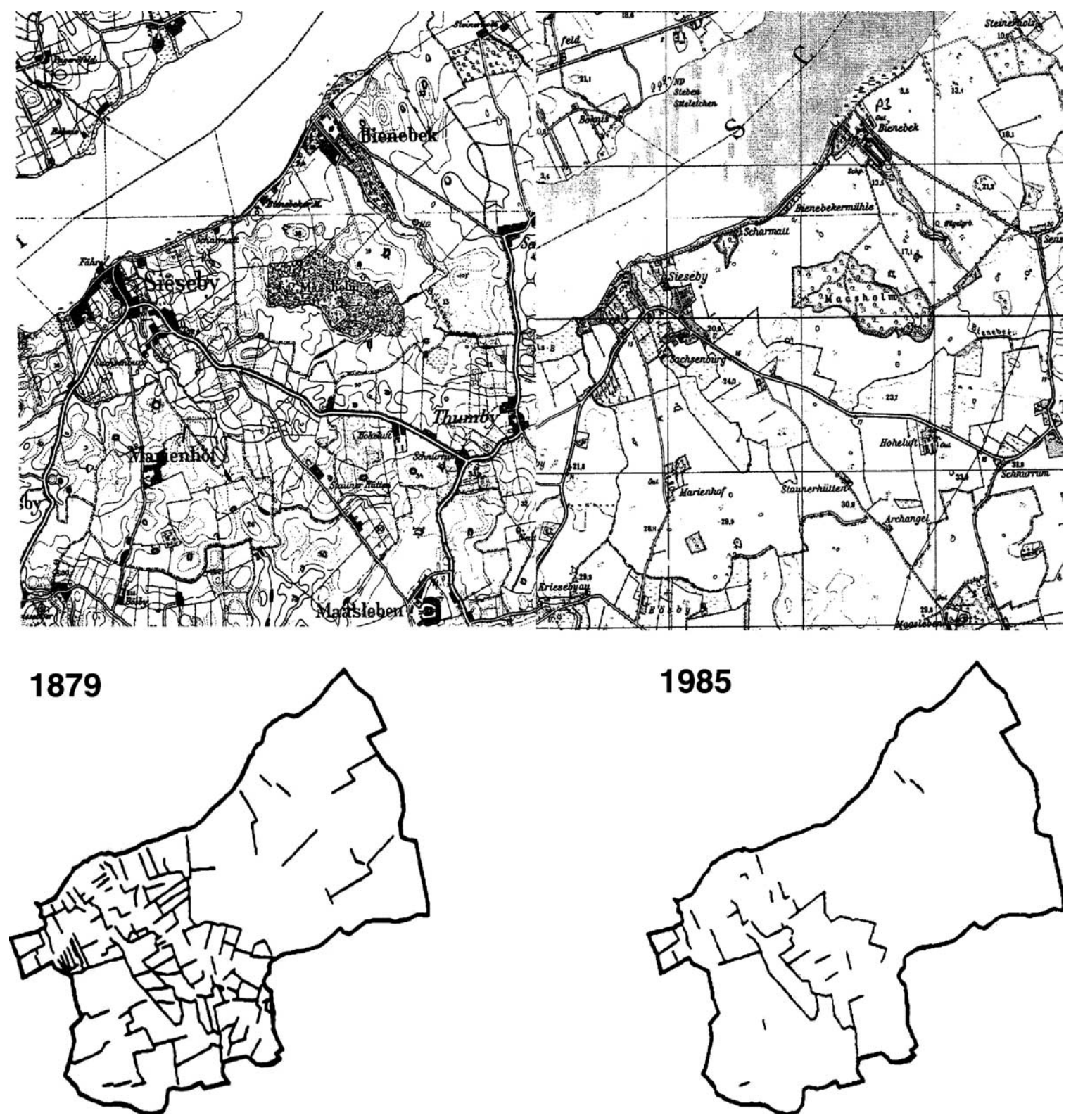

Fig. 3. Top: map $(1: 25,000)$ of the district of Bienebeck, Schleswig-Holstein, northern Germany in 1879 (left) and 1985 (right). South of the river "Schlei" the district is already 1879 divided into two parts: the south-western part is characterised by small-sized properties, the north-western part by large scale land ownership dating back to 300 years ago. Bottom: initial situations and developments of both parts between 1879 and 1985 with regard to hedgerow density (Becker, 1998).

However, long-term faunistic and floristic investigations that compared the status after reparcelling of the landscape with the semi-natural situation in a nearby nature reserve did not result in a consider- able reduction of biodiversity or of the percentage of, for instance, "Red List" spider species (Table 6) and other invertebrates (Kobel-Lamparski and Lamparski, 1998; Kobel-Lamparski et al., 1999): moreover, the 

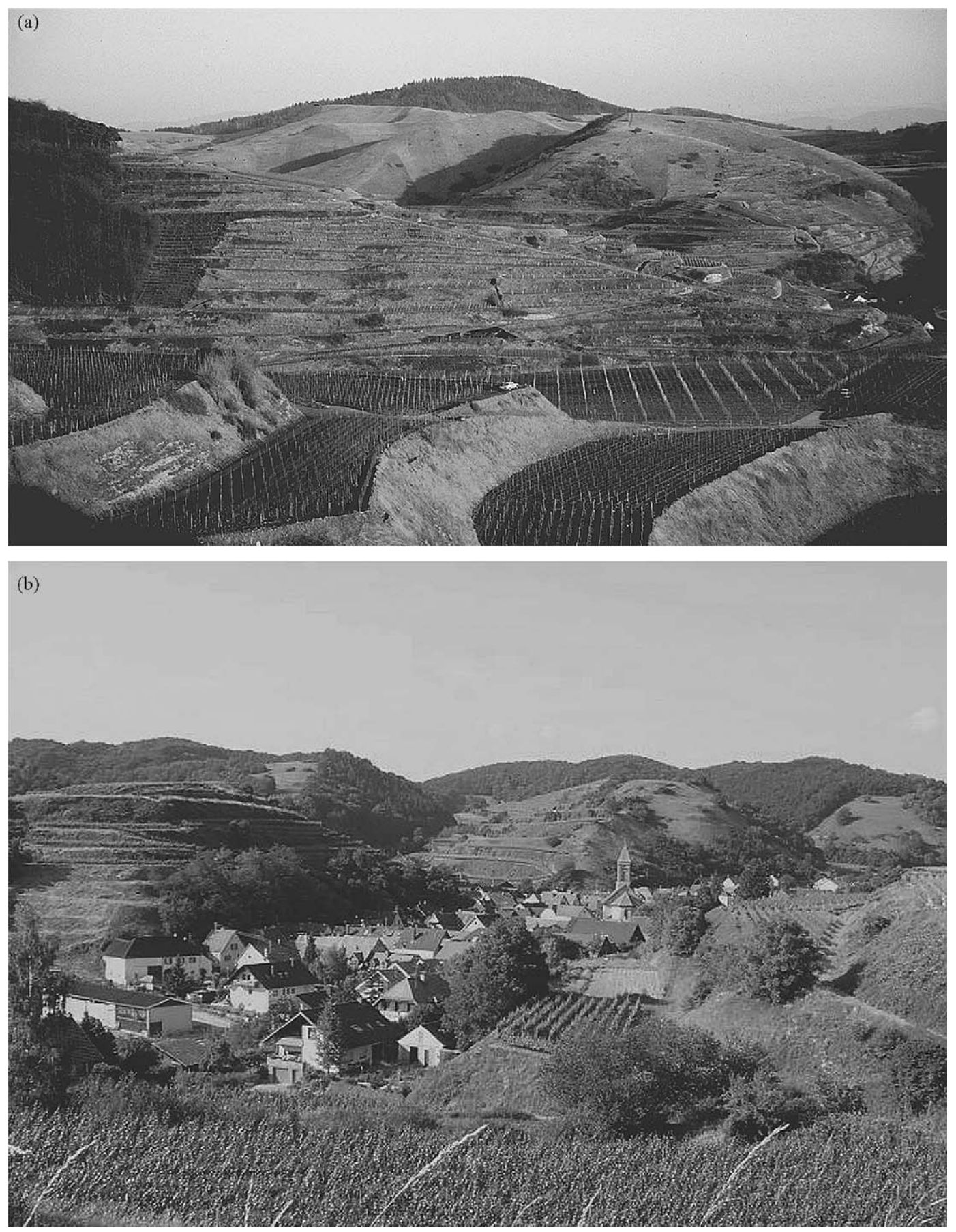

Fig. 4. Vine-growing areas within the Kaiserstuhl region (south-west Germany). (a) View on large terraces and embankments in the foreground which were built approximately 20 years ago, and the dry meadows of the nature reserve "Badberg" in the background which were used as a reference (Kobel-Lamparski and Lamparski, 1998). (b) View on an original vine-growing area with small terraces and embankments near Schellingen (source: htttp://kaiserstuhl.net/cgi-kaiserstuhl/view.cgi?Titel=Schelingen\&Bild=schelingen-01.jpg). 
Table 5

Comparison of two (pairs of) organically managed fields in eastern Germany with different field sizes and richness of landscape structures (Kreuter, 2000, unpublished)

\begin{tabular}{|c|c|c|}
\hline & Field location A & Field location B \\
\hline \multicolumn{3}{|l|}{ Preconditions } \\
\hline Field size & $7.5 / 3.8$ ha & 42.5 ha \\
\hline Landscape structure & Rich & Poor \\
\hline $\begin{array}{l}\text { Soil quality index } \\
\text { "Bodenpunktzahlen" }\end{array}$ & 55 & $30-75$ \\
\hline Crop rotation & $\begin{array}{l}\text { Winter wheat, } \\
\text { oats, winter rye, } \\
\text { winter wheat, } \\
\text { alfalfa, set-aside, } \\
\text { triticale, winter } \\
\text { wheat }\end{array}$ & $\begin{array}{l}\text { Sugar beet, } \\
\text { yellow peas, oats, } \\
\text { winter barley, } \\
\text { winter wheat, } \\
\text { summer barley, } \\
\text { yellow peas }\end{array}$ \\
\hline \multicolumn{3}{|l|}{ Ground beetle situation } \\
\hline \multicolumn{3}{|l|}{ Species number } \\
\hline Total & 106 & 101 \\
\hline Field margin & 92 & 89 \\
\hline Field centre & 82 & 72 \\
\hline \multicolumn{3}{|c|}{ No. of individuals/trap $\times$ days } \\
\hline Total & 5.3 & 6.1 \\
\hline Field margin & 3.4 & 5.8 \\
\hline Field centre & 6.4 & 5.8 \\
\hline
\end{tabular}

All fields belong to the same farm (Ökohof Seeben, SachsenAnhalt) and are situated close by (approximately $5 \mathrm{~km}$ ).

percentage of thermophilic species increased and an intensive exchange of species between embankments and vineyards could be observed. Due to regional climatic conditions the typical fauna of the Kaiserstuhl

Table 6

Comparison of spider communities in an 18-year-old vineyard embankment (built during intensive reparcelling) and in a dry meadow of a nearby nature reservation (Kobel-Lamparski and Lamparski, 1998)

\begin{tabular}{|c|c|c|}
\hline Parameter & $\begin{array}{l}\text { Dry meadow } \\
\text { (Mesobrometum) } \\
\text { nature reservation }\end{array}$ & $\begin{array}{l}\text { Artificial } \\
\text { vineyard } \\
\text { embankment } \\
\text { (18 years old) }\end{array}$ \\
\hline Species numbers & 81 & 85 \\
\hline No. of "Red List" species & 48 & 40 \\
\hline $\begin{array}{l}\text { Percentage of "Red List" } \\
\text { species of total samples }\end{array}$ & 74.9 & 72.0 \\
\hline $\begin{array}{l}\text { No. of non-threatened } \\
\text { species }\end{array}$ & 33 & 35 \\
\hline ind per trap & $405 \pm 82$ & $201 \pm 55$ \\
\hline $\begin{array}{l}\text { Shannon-diversity index } \\
\left(H_{\mathrm{S}}\right)\end{array}$ & 2.92 & 3.09 \\
\hline Evenness & 0.66 & 0.70 \\
\hline
\end{tabular}

area is xerothermophilic. By implementation of the large embankments such locations developed in great numbers that cover $30 \%$ of the area. These large new embankments are not under pressure by human activities, whereas the former small embankments were affected to a greater extent by pesticide fumigation or shading by the vine grapes. Furthermore, the new embankments are not isolated, but linked together and grid-like, spread over the whole vine-growing area, so that they can develop different exposures and structural expressions, resulting in a great variety of microclimatic conditions. Moreover, vine grapes are a permanent crop which allows a long-term development of the species community.

\subsection{Equal arthropod biodiversity at different levels of patchiness and structural complexity of rural landscapes due to the management intensity}

Comparative investigations in a poorly structured and large-sized agricultural area in Poland and a well structured small scale region at Unterfranken (Germany) by Mühlenberg and Slowik (1997) showed that in Poland the same level of insect diversity could be achieved as in Unterfranken, although the patchiness and structural complexity in Poland was remarkably less developed than at the German location (Fig. 5). Obviously, structural complexity of the landscape is not the most decisive factor that guarantees the development of a high biodiversity level. Mühlenberg and Slowik (1997) explain this observation with a

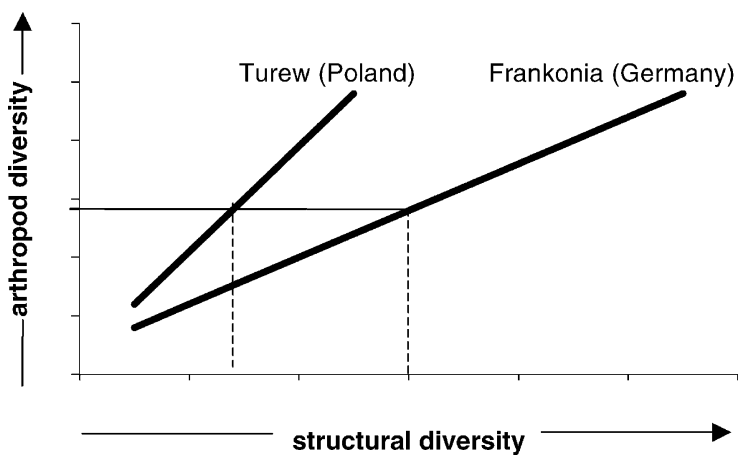

Fig. 5. Model of the development of arthropod species diversity depending on the structural diversity of the landscape according to observations made by Mühlenberg and Slowik (1997) in Poland (Turew) and Germany (Frankonia). 
Table 7

Ground beetle communities (Coleoptera: Carabidae) in winter wheat fields of different size in Sachsen-Anhalt (eastern part of Germany $=$ large-sized fields) and Lower Saxony (western part of Germany $=$ small-sized fields) in 1991-1993 (Volkmar et al., 1994)

\begin{tabular}{|c|c|c|c|c|c|c|c|c|c|}
\hline \multirow{2}{*}{$\begin{array}{l}\text { Study site } \\
\text { Sampling period }\end{array}$} & \multicolumn{3}{|c|}{ Barnstädt (Sachsen-Anhalt) } & \multicolumn{3}{|c|}{ Peißen (Sachsen-Anhalt) } & \multicolumn{3}{|c|}{ Hötzum (Lower Saxony) } \\
\hline & 7 May to 6 August & 9 April to 23 July & 5 April to 8 July & 8 May to 7 August & 8 April to 21 July & 7 April to 8 July & 8 May to 7 August & 9 April to 21 July & 6 April to 6 July \\
\hline Year & 1991 & 1992 & 1993 & 1991 & 1992 & 1993 & 1991 & 1992 & 1993 \\
\hline Field size (ha) & 141.0 & 139.0 & 43.0 & 24.0 & 24.0 & 24.0 & 6.0 & 6.0 & 6.0 \\
\hline No. of species & 32 & 26 & 37 & 36 & 38 & 39 & 19 & 22 & 24 \\
\hline ind per trap & 50.0 & 42.5 & 354.9 & 97.6 & 117.3 & 183.2 & 590.9 & 30.3 & 58.2 \\
\hline Shannon-diversity index $\left(H_{\mathrm{S}}\right)$ & 2.59 & 2.60 & 2.14 & 2.48 & 2.74 & 2.85 & 1.09 & 1.97 & 1.18 \\
\hline Evenness & 0.75 & 0.8 & 0.59 & 0.69 & 0.75 & 0.78 & 0.37 & 0.64 & 0.37 \\
\hline No. of dominant spe & 5 & 6 & 6 & 7 & 6 & 8 & 4 & 3 & 2 \\
\hline \multirow[t]{6}{*}{ Dominant carabid species ${ }^{\mathrm{a}}$} & $\begin{array}{l}\text { Harpalus aeneus } \\
(17.8 \%)\end{array}$ & $\begin{array}{l}\text { Calosoma } \\
\text { auropunctatum } \\
(14.6 \%)\end{array}$ & $\begin{array}{l}\text { Poecilus cupreus } \\
(35.8 \%)\end{array}$ & $\begin{array}{l}\text { Poecilus cupreus } \\
(21.1 \%)\end{array}$ & $\begin{array}{l}\text { Poecilus cupreus } \\
(19.5 \%)\end{array}$ & $\begin{array}{l}\text { Calathus fuscipes } \\
(14.5 \%)\end{array}$ & $\begin{array}{l}\text { Pterostichus } \\
\text { melanarius } \\
(52.9 \%)\end{array}$ & $\begin{array}{l}\text { Pterostichus } \\
\text { melanarius } \\
(46.2 \%)\end{array}$ & $\begin{array}{l}\text { Pterostichus } \\
\text { melanarius } \\
(74.7 \%)\end{array}$ \\
\hline & $\begin{array}{l}\text { Pseudophonus } \\
\text { rufipes (16.9\%) }\end{array}$ & $\begin{array}{l}\text { Pseudophonus } \\
\text { rufipes (12.8\%) }\end{array}$ & $\begin{array}{l}\text { Harpalus } \\
\text { distinguendus } \\
(17.1 \%)\end{array}$ & $\begin{array}{l}\text { Amara familiaris } \\
(17.3 \%)\end{array}$ & $\begin{array}{l}\text { Anchomenus } \\
\text { dorsalis }(12.0 \%)\end{array}$ & $\begin{array}{l}\text { Harpalus aeneus } \\
(11.5 \%)\end{array}$ & $\begin{array}{l}\text { Trechus } \\
\text { quadristriatus } \\
(38.4 \%)\end{array}$ & $\begin{array}{l}\text { Loricera } \\
\text { pilicornis } \\
(15.5 \%)\end{array}$ & $\begin{array}{l}\text { Clivina fossor } \\
(6.9 \%)\end{array}$ \\
\hline & $\begin{array}{l}\text { Anchomenus dorsalis } \\
(13.1 \%)\end{array}$ & $\begin{array}{l}\text { Anchomenus dorsalis } \\
(12.0 \%)\end{array}$ & $\begin{array}{l}\text { Anchomenus dorsalis } \\
(12.5 \%)\end{array}$ & $\begin{array}{l}\text { Pseudophonus } \\
\text { rufipes }(10.7 \%)\end{array}$ & $\begin{array}{l}\text { Amara familiaris } \\
(11.5 \%)\end{array}$ & $\begin{array}{l}\text { Poecilus punctulatus } \\
(9.5 \%)\end{array}$ & $\begin{array}{l}\text { Clivina fossor } \\
(2.5 \%)\end{array}$ & $\begin{array}{l}\text { Anchomenus } \\
\text { dorsalis } \\
(11.2 \%)\end{array}$ & $\begin{array}{l}\text { Other carabid } \\
\text { species } \\
(18.4 \%)\end{array}$ \\
\hline & $\begin{array}{l}\text { Demetrias } \\
\text { atricapillas }(10.2 \%)\end{array}$ & $\begin{array}{l}\text { Harpalus aeneus } \\
(11.5 \%)\end{array}$ & $\begin{array}{l}\text { Microlestes } \\
\text { minutulus }(9.0 \%)\end{array}$ & $\begin{array}{l}\text { Bembidion lampros } \\
(9.4 \%)\end{array}$ & $\begin{array}{l}\text { Harpalus aeneus } \\
(8.7 \%)\end{array}$ & $\begin{array}{l}\text { Poecilus cupreus } \\
(9.4 \%)\end{array}$ & \begin{tabular}{|l} 
Pterostichus \\
niger (2.4\%)
\end{tabular} & $\begin{array}{l}\text { Other carabid } \\
\text { species } \\
(27.1 \%)\end{array}$ & \\
\hline & $\begin{array}{l}\text { Amara familiaris } \\
(9.3 \%) \\
\text { Other carabid } \\
\text { species }(32.7 \%)\end{array}$ & $\begin{array}{l}\text { Poecilus cupreus } \\
(11.5 \%) \\
\text { Harpalus } \\
\text { distinguendus } \\
(11.0 \%)\end{array}$ & $\begin{array}{l}\text { Harpalus aeneus } \\
(6.4 \%) \\
\text { Poecilus punctulatus } \\
(3.8 \%)\end{array}$ & $\begin{array}{l}\text { Harpalus aeneus } \\
(8.9 \%) \\
\text { Pterostichus } \\
\text { melanarius }(8.4 \%)\end{array}$ & $\begin{array}{l}\text { Pterostichus } \\
\text { melanarius }(6.1 \%) \\
\text { Calosoma } \\
\text { auropunctatum } \\
(5.9 \%)\end{array}$ & $\begin{array}{l}\text { Anchomenus dorsalis } \\
(6.7 \%) \\
\text { Microlestes } \\
\text { minutulus }(6.3 \%)\end{array}$ & $\begin{array}{l}\text { Other carabid } \\
\text { species }(3.8 \%)\end{array}$ & & \\
\hline & & $\begin{array}{l}\text { Other carabid } \\
\text { species }(26.6 \%)\end{array}$ & $\begin{array}{l}\text { Other carabid } \\
\text { species }(15.4 \%)\end{array}$ & $\begin{array}{l}\text { Calathus fuscipes } \\
\text { (7.7\%) } \\
\text { Other carabid } \\
\text { species }(16.4 \%)\end{array}$ & $\begin{array}{l}\text { Other carabid } \\
\text { species }(36.4 \%)\end{array}$ & $\begin{array}{l}\text { Pterostichus } \\
\text { melanarius }(5.8 \%) \\
\text { Calosoma } \\
\text { auropunctatum } \\
(5.5 \%) \\
\text { Other carabid } \\
\text { species (30.7\%) }\end{array}$ & & & \\
\hline
\end{tabular}


generally far more extensive land use (crop management) in Poland compared to Germany. This conclusion is stated by Volkmar et al. (1994), who recorded significantly lower species numbers of ground beetles (Coleoptera: Carabidae) in comparatively small, but intensively managed fields (6 ha) in the West Germany "Hildesheimer Börde" in comparison to large-sized fields (24 and 141 ha) in the East Germany "Magdeburger Börde" (Table 7). Moreover, derived from the knowledge on the ecology of the ground beetles recorded, most species of the small-scaled western location could be classified as "indicators for intensification" (Büchs et al., 1999).

The intention of the examples above is to demonstrate that environmental measures which aim to maximise "biodiversity" as the nominal number of species without consideration of quality aspects (e.g. stenoecious or habitat-specific species) or other topics belonging to the hierarchic model of Noss (1990), and which are applied on a nation-wide scale without any differentiation could be misleading. It was shown that environmental goals and measures have to be adopted very specifically depending on the regional geographical unit, and that landscape-related historical and socio-economic developments have to be considered.

\section{Conclusion}

There are numerous ecological parameters for both the population and community level that are suitable as assessment criteria in the outlined area. The definition of which goal the assessment should be orientated towards is decisive for its methods and modalities. It has to be defined which qualities of a system are assessed as good or worthwhile and which as bad or unconditional. However, if (species-)diversity and/or a maximum of "rare" and "endangered" species are not identified as the positive goal criterion, but the development of a species community typical for the investigated ecosystem or geographical unit, respectively, then it can be assumed that all parameters which describe reproduction conditions or reproduction success of (animal) populations in any form will belong to the essential assessment criteria. For instance, only healthy populations (precondition: e.g. a sufficient food basis) which have the possibility of re- producing successfully (precondition: e.g. an area size adapted to the demands of the species and suitable habitat resources) safeguard the survival of a species. Therefore, (if applied to the whole species community of an ecosystem) healthy populations guarantee the conservation of biodiversity, but also of beneficial aspects (e.g. predation, parasitation, decomposition) on a high level. Therefore, the "physical fitness" of populations of wild animal and plant species typical in agro-ecosystems can be estimated as a decisive measure for the seriousness of the conversion of consumer protection interests into action with regard to food production.

A number of examples shows that "biodiversity" in the sense of maximising the number of species, varieties, genotypes, etc. is a misleading and, as such, not a suitable criterion for indication approaches. Moreover, the review-like analysis demonstrated that "biodiversity" is a much more complex term that consists in various facets each of them contributing to "biodiversity" in its entirety like pieces of a jigsaw puzzle. However, it could be also shown that biotic indicator approaches relying on such "puzzle pieces" (like, for instance, parameters relying on reproduction and/or physical fitness) might be thoroughly appropriate to give indications of the development of biodiversity as such.

With regard agro-ecosystems the central platform for the action of these organisms (i.e. their functional importance) is the cultivated area itself. Therefore, highest priority has to be granted to the preservation of the essential resources required by those agrobiocoenoses that are typical for the region and the relevant geographical unit, so that assessments should not be restricted to marginal or uncultivated habitats in rural landscapes, but mainly focus on the cropped area itself.

Although ecological sciences are obvious able to provide a set of indicators suitable for a detailed and predictive analysis of nearly any situation affecting the agro-ecosystems, they do not hit the demands of those institutions (mostly administrations) who need to apply such indicators in practice. Spoiled by the easy handling of abiotic indicators administrations expect that:

- (biotic) indicators are easy to assess and to understand; 
- interpretations, statements and predictions are safe and easy, i.e. that they can be expressed by numerical measures and baseline reference values as well as thresholds which are clearly defined so that they are legally valid;

- best one (biotic) indicator is able to represent and characterise an ecosystem as a whole and all processes going off within;

- as far as possible no extra data surveys have to be conducted.

In a nutshell, derived from experience with abiotic indicators, also biotic indicators are expected to produce omnipotential "technical" values.

Furthermore, in order to be able to manage the continuously increasing number of (biotic and abiotic) indicators and in order to fit in the financial limitations, administration tend to aggregate data and to reduce the number of indicators that are used. This tendency, which is basically understandable, increases with the administration level and ends up in the use of highly aggregated indicators the power of statement of which is rather weak and general (e.g. number of bird species with breeding records or percentage of organic farming). These scenarios lead at least to three consequences with regard biotic indicators:

(a) The status of each biotic indicators has to be reviewed: it has to be critically discussed whether agri-environmental biotic indicators as recently still more or less neglected parts within established assessment systems a more important role has to be acknowledged as it is currently realised within the control of the quality of freshwater habitats: nearly each local office for freshwater control has someone employed who is responsible for biotic assessment of freshwater ecosystems by the "Saprobia index" which, for instance, needs a regular update of data by field surveys and a rather detailed taxonomic work. The fact that budget will not be increased in order to fulfil these new tasks is an argument frequently used against the intensification of labour in the area of routine biotic assessment procedures in terrestrial ecosystems. However, possibilities of reorganisation seem not to be fully exhausted and the example of fresh water management shows to what extent biotic assessments can be realised. (b) The paper showed clearly that depending on the geographic level considered (e.g. if an indicator is used to assess the environmental situation of a field, of a whole farm, a region or a country) and on the goals that should be achieved an indicator has to fulfil different requirements. Therefore, the establishment of a hierarchic system of indicators (particularly biotic ones) including their linking-up considering the different levels/goals mentioned is needed as well on the scientific as on the administrative side. This should be linked with automatic control procedures (represented by committees with different composition regarding the kind and level of experts) which safeguard a regular control of quality and suitability of those indicators in use, but also check indicator approaches not in official use in order to guarantee that developments are not overlooked, and which have the power to exchange indicators that are identified as inappropriate or if the focus of society has changed, respectively. However, as far as it can be judged up to date a consistent and well accepted (hierarchical) system particularly of biotic indicators which covers and integrates all "geographic" levels and different goals of assessment is completely lacking.

(c) If the current practice will be continued, surrogate indicators will be the only choice to hit the demands of the administration mentioned above. However, the misleading potential of those indicators was illustrated in Sections 5.15.5. Nevertheless, under the current conditions surrogate indicators will be the only way out of the dilemma of biotic assessments. Thus, the main focus in research on biotic indicators for the forthcoming years seems to be whether statements on and predictions of biodiversity development derived from surrogate indicators (as, for instance, percentage of "ecological priority areas", length of hedgerows, field margins, weed strips, field size, pesticide and fertiliser input) are correlated to quantitative (number of species, varieties, genotypes and their abundance) as well as qualitative (e.g. fitness, percentage of stenotopic, rare or functionally important species, functional responses, etc.) features of agricultural areas (e.g. Heyer et al., 2003). 


\section{Acknowledgements}

Many thanks to I. Bürig (Braunschweig) for her intensive engagement to improve the English.

\section{References}

Achtziger, R., Nickel, H., Schreiber, R., 1999. Auswirkungen von Extensivierungsmaßnahmen auf Zikaden, Wanzen, Heuschrecken und Tagfalter im Feuchtgrünland. Schriftenreihe des Bayerischen Landesamtes für Umweltschutz 150, 109-131.

Altieri, M.A., 1999. The ecological role of biodiversity in agro-ecosystems. Agric. Ecosyst. Environ. 74, 19-31.

Alvarez, T., Frampton, G.K., Goulson, D., 2001. Epigaeic Collembola in winter wheat under organic, integrated and conventional farm management regimes. Agric. Ecosyst. Environ. 83 (1-2), 95-110.

Andelman, S.J., Fagan, W.F., 2000. Umbrellas and flagships: efficient conservation surrogates or expensive mistakes? Proc. Natl. Acad. Sci. U.S.A. 97 (11), 5954-5959.

Andersen, A.N., Ludwig, J.A., Lowe, L.M., Rentz, D.C.F., 2001. Grasshopper biodiversity in Australian tropical savannahs: responses to disturbance in Kakadu National Park. Aust. Ecol. 26, 213-222.

André, H.M., 1976. Introduction a l'etude écologique des communautés de microarthropodes corticoles sonmises a la pollution atmospherique I. Les microhabitats corticoles. Bull. Ecol. 7, 431-444.

Andrzejewska, L., 1976. The influence of mineral fertilization on the meadow phytophagous fauna. Pol. Ecol. Stud. 2, 93-109.

Andrzejewska, L., 1991. Formation of Auchenorrhyncha communities in diversified structures of agricultural landscapes. Pol. Ecol. Stud. 17, 267-287.

Assing, V., 1992. Zur Bionomie von Xantholinus rhenanus COIFF. und anderen bodenbewohnenden Xantholinen (Col., Staphylinidae) in Nordwestdeutschland. Zoologische Jahrbücher für Systematik 115, 495-508.

Banks, C.J., 1959. Experiments with suction traps to assess the abundance of Syrphidae (Diptera), with special reference to aphidophagous species. Entomologia Experimentalis et Applicata 2, 110-124.

Bartels, G., Kampmann, T. (Eds.), 1994. Auswirkungen eines langjährigen Einsatzes von Pflanzenschutzmittel bei unterschiedlichen Intensitätsstufen und Entwicklung von Bewertungskriterien. Mitteilungen aus der Biologischen Bundeanstalt für Land- und Forstwirtschaft 295, 1405.

Basedow, T., 1988. Feldrand, Feldrain und Hecke aus der Sicht der Schädlingsregulation. Mitteilungen aus der Biologischen Bundesanstalt für Land- und Forstwirtschaft 247, 129-137.

Basedow, T., 1990. Jährliche Vermehrungsraten von Carabiden und Staphyliniden bei unterschiedlicher Intensität des Ackerbaus. Zoologische Beiträge 33, 459-477.

Basedow, T., 1998. Langfristige Bestandsveränderungen von Arthropoden in der Feldflur, ihre Ursachen und deren Bedeutung für den Naturschutz, gezeigt an Laufkäfern
(Carabidae) in Schleswig-Holstein, 1971-1996. Schriftenreihe für Landschaftspflege und Naturschutz 58, 215-227.

Basedow, T., Braun, C., Lühr, A., Naumann, J., Norgall, T., Yanes, G., 1991. Biomasse und Artenzahl epigäischer Raubarthropoden auf unterschiedlich intensiv bewirtschafteten Weizen- und Rübenfeldern: Unterschiede und ihre Ursachen. Ergebnisse eines dreistufigen Vergleichs in Hessen, 1985 bis 1988. Zoologische Jahrbücher für Systematik 118, 87-116.

Basedow, T., Tóth, F., Kiss, J., 1999. The species composition and frequency of spiders in fields of winter wheat in Hungary (north-east of Budapest) and in Germany (north of Frankfurt/M.). An attempt of comparison. Mitteilungen der Deutschen Gesellschaft für allgemeine und angewandte Entomologie 12, 166-263.

Becker, W., 1998. Die Eigenart der Kulturlandschaft-Bedeutung und Strategien für die Landschaftsplanung. VWF Verlag für Wissenschaft und Forschung, Berlin, 281 pp.

Behan-Pelletier, V.M., 1999. Oribatid mite biodiversity in agro-ecosystems role for bioindication. Agric. Ecosyst. Environ. $74,411-423$.

Bick, H., 1982. Bioindikatoren und Umweltschutz. DechenianaHefte 26, 2-5.

Blake, S., Foster, G.N., Eyre, M.D., Luff, M.L., 1994. Effects of habitat type and grassland management practices on the body size distribution of carabid beetles. Pedobiologia 38, 502-512.

Blower, G.J., 1955. Centipedes and millipedes as soil animals. In: Kevan, D.E. (Ed.), Soil Zoology. London, pp. 138-151.

Boatman, N., 1994. Field Margins: Integrating Agriculture and Conservation. British Crop Protection Council, Surrey, UK, 404 pp.

Bohac, J., 1999. Staphylinid beetles as bioindicators. In: Paoletti, M.G. (Ed.), Invertebrate Biodiversity as Bioindicators of Sustainable Landscapes. Agric. Ecosyst. Environ. 74, 357-372.

Bongers, T., 1990. The maturity index: an ecological measure of environmental disturbance based on nematode species composition. Oecologia 83, 14-19.

Braband, D., Geier, U., Köpke, U., 2003. Bio-resource evaluation within agri-environmental assessment tools in different European countries. In: Büchs, W. (Ed.), Biotic Indicators for Biodiversity and Sustainable Agriculture. Agric. Ecosyst. Environ. 98, 423-434.

Brose, U., 2003. Regional diversity of temporary wetland carabid beetle communities: a matter of landscape features or cultivation intensity? In: Büchs, W. (Ed.), Biotic Indicators for Biodiversity and Sustainable Agriculture. Agric. Ecosyst. Environ. 98, $163-167$.

Brown, V.K., Southwood, T.R.E., 1987. In: Gray, A.J., Crawley, M.J., Edwards, D.J. (Eds.), Secondary Succession: Patterns and Strategies. Blackwell Scientific Publications, Oxford, pp. 315-337.

Büchs, W., 1988. Stamm- und Rindenzoozönosen verschiedener Baumarten des Hartholzauenwaldes und ihr Indikatorwert für die Früherkennung von Baumschäden. Ph.D. thesis, University of Bonn, pp. 1-813.

Büchs, W., 1993. Auswirkungen unterschiedlicher Bewirtschaftungsintensitäten auf die Arthropodenfauna von Winterweizenfeldern. Verhandlungen der Gesellschaft für Ökologie 22, $27-34$. 
Büchs, W., 1994. Effects of different input of pesticides and fertilizers on the abundance of arthropods in a sugar beet crop: an example for a long-term risk assessment in the field. In: Donker, M., Eijsackers, H., Heimbach, F. (Eds.), Ecotoxicology of Soil Organisms. Lewis Publishers, Boca Raton, FL, USA, pp. 303-321.

Büchs, W., 1995. Tierökologische Untersuchungen als Grundlage zur Charakterisierung von Ökosystemen und Indikation von Umweltbelastungen. Habilitation thesis, Faculty of Natural Sciences, Technical University of Braunschweig, pp. 1-312.

Büchs, W., Harenberg, A., Zimmermann, J., 1997. The invertebrate ecology of farmland as a mirror of the intensity of the impact of man? An approach to interpreting results of field experiments carried out in different crop management intensities of a sugar beet and an oil seed rape rotation including set-aside. Biol. Agric. Horticult. 15, 83-107.

Büchs, W., Harenberg, A., Prescher, S., Weber, G., Hattwig, F., 1999. Entwicklung von Evertebratenzönosen bei verschiedenen Formen der Flächenstillegung und Extensivierung. In: Büchs, W. (Ed.), Nicht bewirtschaftete Areale in der Agrarlandschaft-ihre Funktionen und ihre Interaktionen mit landnutzungsorientierten Ökosystemen. Mitteilungen aus der Biologischen Bundesanstalt für Land- und Forstwirtschaft Berlin Dahlem 368, 9-38.

Büchs, W., Harenberg, A., Zimmermann, J., Weiß, B., 2003. Biodiversity, the ultimate agroenvironmental indicator? Potential and limits for the application of faunistic elements as gradually indicators in agro-ecosystems. In: Büchs, W. (Ed.), Biotic Indicators for Biodiversity and Sustainable Agriculture. Agric. Ecosyst. Environ. 98, 99-123.

Canard, A., Marc, P., Ysnel, F., 1999. An experimental system to test invertebrate biodiversity by means of spiders. Bull. Br. Arachnol. Soc. 1998, 319-323.

Chiverton, P.A., 1988. Searching behaviour and cereal aphid consumption by Bembidion lampros and Pterostichus cupreus, in relation to temperature and prey density. Entomologia Experimentalis et Applicata 47, 173-182.

Clarke, G.M., 1993. Fluctuating asymmetry of invertebrate population as a biological indicator of environmental quality. Environ. Pollut. 82, 207-211.

Clarke, K.R., Warwick, R.M., 1998. A taxonomic distinctness index and its statistical properties. J. Appl. Ecol. 35 (4), 523531.

Cranston, P.S., Hillman, T., 1992. Rapid assessment of biodiversity using biological diversity technicians. Aust. Biol. 5, 144-154.

Curry, J.P., 1987. The invertebrate fauna of grassland and its influence on productivity. 1. The composition of fauna: grass and forage. Science 42, 103-120.

Curry, J.P., 1994. Grassland Invertebrates-Ecology. Influence on Soil Fertility and Effect on Plant Growth. Chapman \& Hall, London.

Dauber, J., Hirsch, M., Simmering, D., Waldhardt, R., Otte, A., Wolters, V., 2003. Landscape structure as an indicator of biodiversity: matrix effects on species richness. In: Büchs, W. (Ed.), Biotic Indicators for Biodiversity and Sustainable Agriculture. Agric. Ecosyst. Environ. 98, 321-329.
Den Boer, P.J., 1968. Zooökologisch onderzoek op het Biologisch Station Wijster, 1959-1967. Miscellaneous paper. Wageningen 2, 161-181.

Den Boer, P.J., 1977. Dispersal power and survival: carabids in a cultivated countryside. Miscellaneous paper. Wageningen 14, $1-190$.

Dennis, P., Fry, G.L.A., 1992. Field margins: can they enhance natural enemy population densities and general arthropod diversity on farmland? Agric. Ecosyst. Environ. 40, 95-115.

Denno, R.F., 1994. Influence of habitat structure on the abundance and diversity of planthoppers. In: Denno, R.F., Perfect, T.J. (Eds.), Planthoppers-Their Ecology and Management. Chapman \& Hall, New York, pp. 140-160.

Denno, R.F., Roderick, G.F., 1991. Influence of patch size, vegetation structure and host plant architecture on the diversity, abundance and life history styles of sap-feeding herbivores. In: Bell, S.S., McCoy, E.D., Muchinsky, H.R. (Eds.), Habitat Structure: The Physical Arrangement of Objects in Space. Chapman \& Hall, New York, pp. 169-196.

Denys, C., 1997. Fördern Ackerrandstreifen die Artendiversität in einer ausgeräumten Agrarlandschaft? Untersuchungen am Beispiel der Insektengemeinschaften am Beifuß (Artemisia vulgaris L.). Mitteilungen der Deutschen Gesellschaft für allgemeine und angewandte Entomologie 11, 69-72.

D'Hulster, M., Desender, K., 1984. Ecological and faunal studies of Coleoptera in agricultural land. IV. Hibernation of Staphylinidae in agro-ecosystems. Pedobiologia 26, 65-73.

Döring, T.F., Kromp, B., 2003. Which carabid species benefit from organic agriculture? A review of comparative studies in winter cereals from Germany and Switzerland. In: Büchs, W. (Ed.), Biotic Indicators for Biodiversity and Sustainable Agriculture. Agric. Ecosyst. Environ. 98, 153-161.

Döring, T.F., Möller, A., Wehke, S., Schulte, G., Broll, G., 2003. Biotic indicators of carabid species richness on organically and conventionally managed arable fields. In: Büchs, W. (Ed.), Biotic Indicators for Biodiversity and Sustainable Agriculture. Agric. Ecosyst. Environ. 98, 133-139.

Duelli, P., 1992. Mosaikkonzept und Inseltheorie in der Kulturlandschaft. Verhandlungen der Gesellschaft für Ökologie 21, 379-384.

Duelli, P., 1997. Biodiversity evaluation in agricultural landscapes: an approach at two different scales. Agric. Ecosyst. Environ. 62, 81-91.

Duelli, P., Obrist, M.K., 2003. Biodiversity indicators: the choice of values and measures. In: Büchs, W. (Ed.), Biotic Indicators for Biodiversity and Sustainable Agriculture. Agric. Ecosyst. Environ. 98, 87-98.

Eiden, G., Kayadkanian, M., Vidal, C., 2001a. Capturing landscape structures: tools. In: EU-Commission (Ed.), From Land Cover to Landscape Diversity in the European Union. Brussels, Belgium, $11 \mathrm{pp}$.

Eiden, G., Kayadkanian, M., Vidal, C., 2001b. Quantifying landscape structures: spatial and temporal dimensions. In: EU-Commission (Ed.), From Land Cover to Landscape Diversity in the European Union. Brussels, Belgium, 14 pp. (+2 tables and 16 maps). 
Ellenberg, H., Weber, H.E., Düll, R., Wirth, V., Werner, W., Paulißen, D., 1992. Zeigerwerte der Pflanzen in Mitteleuropa. Scripta Geobotanica 18, 1-258.

Engelmann, H.D., 1978. Zur Dominanzklassifizierung von Bodenarthropoden. Pedobiologia 18, 378-380.

European Commission (Ed.), 1991. Verordnung (EWG) Nr. 2092/91 des Rates vom 24. Juni 1991 über den ökologischen Landbau und die entsprechende Kennzeichnung der landwirtschaftlichen Erzeugnisse und Lebensmittel. Amtsblatt der Europäischen Gemeinschaft No. L 198, 22 July 1991, p. 1.

European Commission (Ed.), 2002. Verordnung (EWG) Nr. 473/2002 der Kommission zur Veränderung der Verordnung (EWG) Nr. 2092/91 des Rates über den ökologischen Landbau. Amtsblatt der Europäischen Gemeinschaft No. L 75, 16 March 2002, p. 21.

Fan, Y., Liebman, M., Groden, E., Alford, A.R., 1993. Abundance of carabid beetles and other ground dwelling arthropods in conventional versus low input bean cropping systems. Agric. Ecosyst. Environ. 43, 127-139.

Ferris, R., Humphrey, J.W., 1999. A review of potential biodiversity indicators for application in British forests. Forestry 72, 313328 .

Foissner, W., 1999. Soil protozoa as bioindicators: pros and cons, methods, diversity, representative examples. In: Paoletti, M.G. (Ed.), Invertebrate Biodiversity as Bioindicators of Sustainable Landscapes. Agric. Ecosyst. Environ. 74, 95-112.

Franzen, J., Weber, G., Büchs, W., Larink, O., 1997. Langzeiteinfluß von Pflanzenschutzmitteln auf Dipteren mit bodenlebenden Entwicklungsstadien. Berichte über Landwirtschaft 75, 291-328.

Frieben, B., 1997. Arten- und Biotopschutz durch Organischen Landbau. In: Weiger, H., Willer, H. (Eds.), Naturschutz durch ökologischen Landbau. Bad Dürkheim, Holm, Germany, pp. 73-92.

Frieben, B., 1998. Verfahren zur Bestandsaufnahme und Bewertung von Betrieben des Organischen Landbaus im Hinblick auf Biotop- und Artenschutz und die Stabilisierung des Agrarökosystems. Schriftenreihe Institut für Organischen Landbau 11, Verlag Dr. Köster, Berlin.

Friedrich, G., 1990. Eine Revision des Saprobiensystems. Zeitschrift für Wasser- und Abwasserforschung 23, 141-152.

Fritz-Köhler,

W., 1996. Blatt- und Rüsselkäfer an Ackerunkräutern. Ökologie und Biogeographie in Mitteleuropa und Untersuchungen an ungespritzten Ackerrandstreifen. Agrarökologie 19, 1-138.

Frouz, J., 1999. Use of soil dwelling Diptera (Insecta, Diptera) as bioindicators: a review of ecological requirements and response to disturbance. In: Paoletti, M.G. (Ed.), Invertebrate Biodiversity as Bioindicators of Sustainable Landscapes. Agric. Ecosyst. Environ. 74, 167-186.

Gallego, F.J., Escribano, P., Christensen, S., 2001. Comparability of landscape diversity indicators in the European Union. In: EU-Commission (Ed.), From Land Cover to Landscape Diversity in the European Union. Brussels, Belgium, 12 pp. (+1 map).

Gaston, K.J., 1996. Biodiversity. A Biology of Numbers and Difference. Blackwell, London, UK.
Geipel, K.-H., Kegel, B., 1989. Die Ausbildung der thoracalen Flugmuskulatur von Laufkäferpopulationen ausgewählter Straßenrandbiotope in Berlin (West). Verhandlungen der Gesellschaft für Ökologie 17, 727-732.

Gilgenberg, A., 1986. Die Verteilungsmuster der Carabiden- und Staphylinidenfauna verschieden bewirtschafteter landwirtschaftlicher Flächen sowie eines Waldes. Ph.D. thesis, University of Bonn, $261 \mathrm{pp}$.

Good, J.A., Speight, M.C.D., 1991. Sites of international and national importance for invertebrate fauna: a definition proposed for use in site surveys. Bull. Ir. Biogeogr. Soc. 14, 48-53.

Greiler, H.J., Tscharntke, T., 1991. Artenreichtum von Pflanzen und Grasinsekten auf gemähten und ungemähten Rotationsbrachen. Verhandlungen der Gesellschaft für Ökologie 20, 429-434.

Gruschwitz, M., 1981. Die Bedeutung der Populationsstruktur von Carabidenfaunen für Bioindikation und Standortdiagnose. Mitteilungen der Deutschen Gesellschaft für allgemeine und angewandte Entomologie 3, 126-129.

Hagvar, S., 1994. Log-normal distribution of dominance as an indicator of stressed soil microarthropod communities? Acta Zool. Fennica 195, 71-80.

Hamblin, A.P., 1992. Environmental Indicators of Sustainable Agriculture. BRR, Canberra, Australia.

Hansson, L., Fahrig, L., Merriam, G., 1995. Mosaic Landscapes and Ecological Processes. Chapmann \& Hall, London.

Harenberg, A., 1997. Auswirkungen abgestuft intensiv geführter Anbausysteme in verschiedenen Fruchtfolgen (Raps-, Zuckerrübenfruchtfolge) und einer selbstbegrünenden Dauerbrache auf Spinnen (Arachnida: Araneae). Ph.D. thesis, Faculty of Natural Sciences, Technical University of Braunschweig, Braunschweig, Germany, 276 pp.

Haslett, J.R., 1988. Qualitätsbeurteilung alpiner Habitate: Schwebfliegen (Diptera: Syrphidae) als Bioindikatoren für Auswirkungen des intensiven Skibetriebs auf alpinen Wiesen in Österreich. Zoologischer Anzeiger 220, 179-184.

Hawkins, V., Selman, P., 1994. Landscape ecological planning and the future countryside: a research note. Landsc. Res. 19 (2), 88-94.

Heydemann, B., 1955. Carabiden der Kulturfelder als ökologische Indikatoren. Berichte Wanderversammlung Deutscher Entomologen 7, 172-185.

Heyer, W., Hülsbergen, K.-J., Wittmann, C., Papaja, S., Christen, O., 2003. Field related organisms as possible indicators for evaluation of land use intensity. Agric. Ecosyst. Environ. 98, 453-461.

Hill, M.O., 1979. Twinspan-a Fortran program for arranging multivariate data in an ordered two-way table by classification of the individuals and attrbutes. Cornell University, Ecology and Systematics, Ithaca, NY, USA.

Hill, M.O., Mountford, J.O., Roy, D.B., Bunce, R.G.H., 1999. Ellenberg's indicator values for British plants. ECOFACT vol. 2, Technical Annexure. Monks Wood, Huntingdon, UK, 46 pp. Hingst, R., Irmler, U., Steinborn, H.-A., 1995. Die Laufkäfergemeinschaften in Wald- und Agrarökosystemen Schleswig-Holsteins. Mitteilungen der Deutschen Gesellschaft für allgemeine und angewandte Entomologie 9, 733-737.

Hirsch, M., Pfaff, S., Wolters, V., 2003. The influence of matrix type on flower visitors of Centaurea jacea L.). In: Büchs, 
W. (Ed.), Biotic Indicators for Biodiversity and Sustainable Agriculture. Agric. Ecosyst. Environ. 98, 331-337.

Hoffmann, J., Greef, J.M., 2003. Mosaic indicators-theoretical approach for the development of indicators for species diversity in agricultural landscapes. In: Büchs, W. (Ed.), Biotic Indicators for Biodiversity and Sustainable Agriculture. Agric. Ecosyst. Environ. 98, 387-394.

Hoffmann, J., Kretschmer, H., 2001. Zum Biotop- und Artenschutzwert großer Ackerschläge in Nordostdeutschland. In: Xylander, W., Wicke, G., Büchs, W., Mühle. H. (Eds.), Großräumigkeit/Kleinräumigkeit in der Agrarlandschaft, Peckiana 1, pp. 17-31.

Hoffmann, J., Greef, J.M., Kiesel, J., Lutze, G., Wenkel, K.-O., 2003. Practical example of the mosaic indicators approach. In: Büchs, W. (Ed.), Biotic Indicators for Biodiversity and Sustainable Agriculture. Agric. Ecosyst. Environ. 98, 395-405.

Hokkanen, H., Holopainen, J.K., 1986. Carabid species diversity and activity densities in biologically and conventionally managed cabbage fields. J. Appl. Entomol. 102, 353-363.

Holland, J.M., Frampton, G.K., Cilgi, T., Wratten, S.D., 1994. Arable acronyms analysed-a review of integrated arable farming systems research in western Europe. Ann. Appl. Biol. 125, 399-438.

Hollander, M., Wolfe, D.A., 1973. Nonparametric Statistical Methods. New York, USA, 503 pp.

Hopkin, S.P., Hardisty, G., Martin, M.H., 1986. The woodlouse Porcellio scaber as a biological indicator of zinc, cadmium, lead and copper pollution. Environ. Pollut. 11, 271-290.

Hopkin, S.P., Jones, D.Y., Dietrich, D., 1993. The isopod Porcellio scaber as a monitor of the bioavailability of metals in terrestrial ecosystems: towards a global woodlouse watch scheme. Sci. Total Environ. (Suppl.), 357-365.

Innis, S.A., Naiman, R.J., Elliott, S.R., 2000. Indicators and assessment methods for measuring the ecological integrity of semi-aquatic terrestrial environments. Hydrobiologia 422-423, 111-131.

Irmler, U., 2003. The spatial and temporal pattern of ground beetles (Coleoptera: Carabidae) on fields in northern Germany (Schleswig-Holstein) and their value as ecological indicators. In: Büchs, W. (Ed.), Biotic Indicators for Biodiversity and Sustainable Agriculture. Agric. Ecosyst. Environ. 98, 141-151.

Jeanneret, P., Schüpbach, B., Luka, H., 2003. Quantifying the impact of landscape and habitat features on biodiversity in cultivated landscapes. In: Büchs, W. (Ed.), Biotic Indicators for Biodiversity and Sustainable Agriculture. Agric. Ecosyst. Environ. 98, 311-320.

Jedicke, E., 1994. Biotopverbund. Ulmer, Stuttgart, Germany, 287 pp.

Jones, C.G., Lawton, J.H. (Eds.), 1995. Linking Species and Ecosystems. Chapman \& Hall, New York, USA, 387 pp.

Joy, S., Maity, S.K., Joy, V.C., 2000. Digestive enzymes in Porcellio laevis (Isopoda: Crustacea) as indicator of heavy metal toxicity in soil-biodiversity and environment. Proceedings of the National Seminar on Environmental Biology, pp. 79-86.

Kareiva, P., 1987. Habitat fragmentation and the stability of predator-prey interactions. Nature 326, 388-390.
Kinnunen, H., Järveläinen, K., Pakkala, T., Tiainen, J., 1996. The effects of isolation on the occurrence of farmland carabids in a fragmented landscape. Ann. Zool. Fennici 33, 165-171.

Kleinhenz, A., Büchs, W., 1993. Einfluß verschiedener landwirtschaftlicher Produktionsintensitäten auf die Spinnenfauna in der Kultur Zuckerrübe. Verhandlungen der Gesellschaft für Ökologie 22, 81-88.

Kleinhenz, A., Büchs, W., 1995. Ökologische Aspekte der Spinnenzönosen von Zuckerrübenflächen unter dem Einfluß eines unterschiedlich intensiven Einsatzes landwirtschaftlicher Produktionsmittel. Mitteilungen der Deutschen Gesellschaft für allgemeine und agewandte Entomologie 9, 481-489.

Knauer, N., 1993. Ökologie und Landwirtschaft. Ulmer, Stuttgart, $280 \mathrm{pp}$.

Knüsting, E., Bartels, G., Büchs, W., 1991. Untersuchungen zu Artenspektrum,

fruchtartspezifischer Abundanz und Abundanzdynamik von Regenwürmern bei unterschiedlich hohen landwirtschaftlichen Produktionsintensitäten. Verhandlungen der Gesellschaft für Ökologie 20, 21-27.

Kobel-Lamparski, A., Lamparski, F., 1998. Sukzessionsuntersuchungen im Rebgelände des Kaiserstuhls.

Kobel-Lamparski, A., Lamparski, F., Gack, C., Straub, F., 1999. Erhöhung der Biodiversität in Rebgebieten des Kaiserstuhls durch die Verzahnung von Rebflächen und Rebböschungen. In: Büchs, W. (Ed.), Nicht bewirtschaftete Areale in der Agrarlandschaft-ihre Funktionen und ihre Interaktionen mit landnutzungsorientierten Ökosystemen. Mitteilungen aus der Biologischen Bundesanstalt für Land- und Forstwirtschaft 368, 69-78.

Koehler, H.H., 1999. Predatory mites (Gamasina, Mesostigmata). In: Paoletti, M.G. (Ed.), Invertebrate Biodiversity as Bioindicators of Sustainable Landscapes. Agric. Ecosyst. Environ. 74, 395-410.

Köhler, F., 1998. Zur Bestandssituation an Ackerunkräutern lebender Blatt- und Rüsselkäferarten in Deutschland (Coleoptera, Chrysomelidae, Curculionidae s.l.). Schriftenreihe Landesanstalt für Pflanzenbau und Pflanzenschutz RheinlandPfalz 6, 243-254.

Köhler, F., Stumpf, T., 1992. Die Käfer der Wahner Heide in der Niederrheinischen Bucht bei Köln (Insecta: Coleoptera). Decheniana-Beihefte 31, 499-593.

Konold, W., 1996. Naturlandschaft Kulturlandschaft-Die Veränderung der Landschaften nach der Nutzbarmachung durch den Menschen. Ecomed, Landsberg, Germany, 322 pp.

Kratochwil, A., Schwabe, A., 2001. Ökologie der Lebensgemeinschaften. UTB 8199, Ulmer, Stuttgart, 756 pp.

Kratz, R., Pfadenhauer, J., 2001. Ökosystemmanagement für Niedermoore. Strategien und Verfahren zur Renaturierung. Ulmer, Stuttgart.

Krause, U., Poehling, H.M., 1996. Overwintering, oviposition and population dynamics of hoverflies (Diptera: Syrphidae) in northern Germany in relation to small and large scale structure. Acta Jutlandica 71, 157-169.

Krebs, C.J., 1999. Ecological Methodology. Addison-Wesley, Menlo Park.

Kreuter, T., 2000. Zur Struktur, Dynamik und bioindikatorischer Eignung von Laufkäferzönosen im Nordteil des Ökohofes 
Seeben. UZU-Schriftenreihe, Neue Folge, Sonderband, pp. $135-171$.

Krivosheina, M.G., 1993. Variation of the wing venation in the species of the genus Dicranomyia stephens (Diptera, Limoniidae) under conditions of high radioactive background level. In: Proceedings of the Fourth Meeting on Species and its Productivity in Distribution Area, UNESCO MAB program, Gidrometeoizdat, St. Petersburg, pp. 267-268.

Krivosheina, M.G., 1995. Different reactions of two populations of Pegomya tenera Ztt. (Diptera, Anthomyiidae) breeding on fungi polluted by ${ }^{137} \mathrm{Cs}$ and ${ }^{90} \mathrm{Sr}$. In: Bohac, J., Triska, J., Tichy, R. (Eds.), Abstracts of the Eighth International Bioindicators Symposium, Ceske Budejovice, 58 pp.

Kromp, B., 1990. Carabid beetles (Coleoptera, Carabidae) as bioindicators in biological and conventional farming in Austrian potato fields. Biol. Fertil. Soils 9, 182-187.

Kromp, B., 1999. Carabid beetles in sustainable agriculture: a review on pest control efficacy, cultivation impacts and enhancement. In: Paoletti, M.G. (Ed.), Invertebrate Biodiversity as Bioindicators of Sustainable Landscapes. Agric. Ecosyst. Environ. 74, 187-228.

Kruess, A., Tscharntke, T., 1994. Habitat fragmentation, parasitoid species loss, and biological control. Science 264, 1581-1584.

Kühle, J.C., 1986. Modelluntersuchungen zur strukturellen und ökotoxikologischen Belastung von Regenwürmern in Weinbergen Mitteleuropas (Oligochaeta: Lumbricidae). Ph.D. thesis, Math.-Nat. Faculty, University of Bonn, Bonn, 390 pp.

Lambeck, R.J., 1997. Focal species: a multi-species umbrella for nature conservation. Conserv. Biol. 11, 849-856.

Langmaack, M., Land, S., Büchs, W., 2001. Effects of different field management systems on the ground beetle coenosis in oil seed rape with special respect to ecology and nutritional status of predacious Poecilus cupreus (Coleoptera: Carabidae). J. Appl. Entomol. 125, 313-320.

Larink, O., Heisler, C., Söchtig, W., Lübben, B., Wickenbrock, L., 1993. Einfluß verdichteter Ackerböden auf die Bodenfauna und ihr Beitrag zur Bodenlockerung. KTBL-Schrift 362, 142-156.

Larsen, K.J., Brewer, S.R., Taylor, D.H., 1994. Differential accumulation of heavy metals by web spiders and ground spiders in an old field. Environ. Toxicol. Chem. 13 (3), 503508.

Lawton, J.H., Gaston, K.J., 2001. Indicator species. In: Levin, S.A. (Ed.), Encyclopedia of Biodiversity, vol. 3. Academic Press, San Diego, pp. 437-450.

Lawton, J.H., Bignell, D.E., Bolton, B., Bloemers, G.F., Eggleton, P., Hammond, P.M., Hodda, M., Holt, R.D., Larsen, T.B., Mawdsley, N.A., Stork, N.E., Srivastava, D.S., Watt, A.D., 1998. Biodiversity inventories, indicator taxa and effects of habitat modification in tropical forest. Nature 391, 72-76.

Linden, D.R., Hendrix, P.F., Coleman, D.C., van Vliet, P.C.J., 1994. Faunal indicators of soil quality. In: Doran, J.W., Coleman, D.C., Bezdicek, D.F., Stewart, B.A. (Eds.), Defining Soil Quality for a Sustainable Environment. SSSA Special Publication 35, USA, pp. 91-106.

Lobry de Bruyn, L.A., 1997. The status of soil macrofauna as indicators of soil health to monitor the sustainability of Australian agricultural soils. Ecol. Entomol. 23, 167-178.
Lorenz, E., 1994. Mechanische Unkrautbekämpfungsverfahren in Zuckerrübenkulturen und ihre Nebenwirkungen auf Laufkäfer (Coleoptera, Carabidae) und andere epigäische Arthropoden. Ph.D. thesis, Faculty of Agriculture, University of Göttingen.

Luka, H., 1996. Laufkäfer: Nützlinge und Bioindikatoren in der Landwirtschaft. Agrarforschung 3 (1), 33-36.

Macarthur, R., Wilson, E.O., 1967. The Theory of Island Biography. Princeton University Press, Princeton.

Majer, J.D., 1983. Ants: bio-indicators of minesite rehabilitation, landuse and land conservation. Environ. Manage. 7, 375-383.

Majer, J.D., Nichols, O.G., 1998. Long-term recolonization patterns of ants in Western Australian rehabilitated bauxite mines with reference to their use as indicators in restoration processes. J. Appl. Ecol. 35, 161-182.

Manly, B.F.J., 1992. The Design and Analysis of Research Studies. Cambridge University Press, Cambridge.

Maraun, M.S., Visser, S., Scheu, S., 1998. Oribatid mites enhance the recovery of the microbial community after a strong disturbance. Appl. Soil Ecol. 9, 18-175.

Marc, P., Canard, A., Ysnel, F., 1999. Spiders (Araneae) useful for pest limitation and bioindication. In: Paoletti, M.G. (Ed.), Invertebrate Biodiversity as Bioindicators of Sustainable Landscapes. Agric. Ecosyst. Environ. 74, 229-273.

Marten, M., Reusch, H., 1992. Anmerkungen zur DIN "Saprobien index" (38 410 Teil 2) und Forderung alternativer Verfahren. Natur und Landschaft 67, 544-547.

Martin, D., 1972. Die Spinnenfauna des Frohburger Raumes. II. Micryphantidae. III. Linyphiidae. IV. Theridiidae. Abhandlungen und Berichte des Naturkundlichen Museums "Mauritianum" Altenburg 7 (2-3), 239-284.

Martin, D., 1973. Die Spinnenfauna des Frohburger Raumes. V. Agelenidae, Argyronetidae, Hahniidae und Hersiliidae. VI. Ctenidae, Lycosidae und Psiauridae. VII. Drassodidae, Anyphaenidae, Clubionidae und Eusparassidae. VIII. Salticidae. IX. Thomisidae und Philodromidae. X. Atypidae, Dysderidae, Sicariidae, Pholcidae, Nesticidae, Mimetidae, Dictynidae, Amaurobiidae und Uloboridae. Abhandlungen und Berichte des Naturkundlichen Museums "Mauritianum" Altenburg 8, 27-57, 127-159.

Mattheis, A., Otte, A., 1994. Ergebnisse der Erfolgskontrollen zum "Ackerrandstreifenprogramm" im Regierungsbezirk Oberbayern 1985-1991. In: Stiftung Naturschutz Hamburg, Stiftung zum Schutze gefährdeter Pflanzen, Flora und Fauna der Äcker und Weinberge, Schriftenreihe Aus Liebe zur Natur 5, 56-71.

Maurer, R., Hänggi, A., 1990. Katalog der schweizerischen Spinnen. Doc. Faun. Helvet. 12, 1-412.

May, R.M., 1980. Theoretische Ökologie. Weinheim, 284 pp.

McGeoch, M.A., 1998. The selection, testing and application of terrestrial insects as bioindicators. Biol. Rev. 73, 181-201.

McGrady-Steed, J.P., Harris, P., Morin, P., 1997. Biodiversity regulates ecosystem predictability. Nature 390, 162-165.

Menge, M., 2003. Experiences with the application, survey and assessment of agri-environmental indicators in agricultural practice. In: Büchs, W. (Ed.), Biotic Indicators for Biodiversity and Sustainable Agriculture. Agric. Ecosyst. Environ. 98, 443-451. 
Moreby, S.J., Aebisher, N.J., 1992. Invertebrate abundance on cereal fields and set-aside land: implications for wild gamebird chicks. In: Clarke, J. (Ed.), Set-Aside. BCPC-Monograph No. 50, pp. 181-186.

Morris, M.G., 1973. The effect of seasonal grazing on the Heteroptera and Auchenorrhyncha (Hemiptera) of chalk grassland. J. Appl. Ecol. 10, 761-780.

Morris, M.G., 1981a. Responses of grassland invertebrates to management by cutting. III. Adverse effects of Auchenorrhyncha. J. Appl. Ecol. 18, 107-123.

Morris, M.G., 1981b. Responses of grassland invertebrates to management by cutting. IV. Positive responses of Auchenorrhyncha. J. Appl. Ecol. 18, 763-771.

Morris, M.G., 1992. Responses of Auchenorrhyncha (Homoptera) to fertilizer and liming treatments at Park Grass, Rothamsted. Agric. Ecosyst. Environ. 41, 263-283.

Morris, M.G., Plant, R., 1983. Responses of grasland invertebrates to management by cutting. V. Changes in Hemiptera following cessation of management. J. Appl. Ecol. 20, 157-177.

Morris, M.G., Rispin, W.E., 1987. Abundance and diversity of the coleopterous fauna of a calcareous grassland under different cutting regimes. J. Appl. Ecol. 24, 451-465.

Motulsky, H., 1995. Intuitive Biostatistics. Oxford University Press, Oxford, UK.

Mühlenberg, M., Slowik, J., 1997. Kulturlandschaft als Lebensraum, UTB 1947. Quelle \& Meyer, 312 pp.

Müller, L., 1991. Auswirkungen der Extensivierungsförderung auf Wirbellose. Faunistisch-Ökologische Mitteilungen Suppl. 10, 41-70.

Murdoch, W., Evans, F.C., Peterson, C.H., 1972. Diversity and pattern in plants and insects. Ecology (New York) 53, 819-829.

Naeem, S., Li, S., 1997. Biodiversity enhances ecosystem reliability. Nature 390, 507-509.

Naeem, S., Thompson, S., Lawler, S., Lawton, J., Woodfin, R., 1994. Declining biodiversity can alter the performance of ecosystems. Nature 368, 734-737.

Nentwig, W. (Ed.), 2000. Streifenförmige ökologische Ausgleichsflächen in der Kulturlandschaft: Ackerkrautstreifen, Buntbrache, Feldränder. Vaö, Bern.

Nentwig, W., Hänggi, A., Kropf, C., Blick, T., 2000. Central European Spiders-Determination Key. http://zoology.unibe. ch/araneae.

Nickel, H., Achtziger, R., 1999. Wiesen bewohnende Zikaden (Auchenorrhyncha) im Gradienten von Nutzungsintensität und Feuchte. Beiträge zur Zikadenkunde 3, 65-80.

Nickel, H., Hildebrandt, J., 2003. Auchenorrhyncha communities as indicators of disturbance in grasslands (Insecta, Hemiptera) a case study from the Elbe flood plains (northern Germany). In: Büchs, W. (Ed.), Biotic Indicators for Biodiversity and Sustainable Agriculture. Agric. Ecosyst. Environ. 98, 183-199.

Noss, R.F., 1990. Indicators for monitoring biodiversity: a hierarchical approach. Conserv. Biol. 4, 355-364.

Novotný, V., 1994a. Relation between temporal persistence of host plants and wing length in leafhoppers (Auchenorrhyncha, Hemiptera). Ecol. Entomol. 19, 168-176.

Novotný, V., 1994b. Association of polyphagy in leafhoppers (Auchenorrhyncha, Hemiptera) with unpredictable environments. Oikos 70, 223-232.
Novotný, V., 1995. Relationships between life histories of leafhoppers (Auchenorrhyncha: Hemiptera) and their host plants (Juncaceae, Cyperaceae, Poaceae). Oikos 73, 33-42.

Nyfeller, M., 1982. Field studies on the ecological role of the spiders as insect predators in agro-ecosystems (abandoned grassland, meadows and cereal fields). Ph.D. thesis, Swiss Federal Institute of Technology, Zurich, Switzerland.

Odum, E.P., 1980. Grundlagen der Ökologie. Georg Thieme, Stuttgart, New York, 836 pp.

Oliver, I., Beattie, A.J., 1996. Invertebrate morphospecies as surrogates for species: a case study. Conserv. Biol. 10, 99-109.

Palmer, A.R., Strohbeck, C., 1986. Fluctuating asymmetry: measurement, analysis, patterns. Annu. Rev. Ecol. Syst. 1, 391421.

Pankhurst, C.E., 1994. Biological indicators of soil health and sustainable productivity. In: Greenland, D.J., Szabolcs, I. (Eds.), Soil Resilience and Sustainable Land Use. CAB International, Wallingford, pp. 331-352.

Pankhurst, C.E., Hawke, B.G., McDonald, H.J., Kirkby, C.A., Buckerfield, J.C., Michelson, P., O’Brien, K.A., Gupta, V.S.S.R., Doube, B.M., 1995. Evaluation of soil biota properties as potential bioindicators of soil health. Aust. J. Exp. Agric. 35, 1015-1028.

Paoletti,

M.G., 1984. La vegetazione spontanea dell' agroecosistema ed il controllo dei fitofagi del mais. Giornate Fitopatologiche 1984, Cleub Bologna, pp. 445-456.

Paoletti, M.G., 1999a. Using bioindicators based on biodiversity to assess landscape sustainability. In: Paoletti, M.G. (Ed.), Invertebrate Biodiversity as Bioindicators of Sustainable Landscapes. Agric. Ecosyst. Environ. 74, 1-18.

Paoletti, M.G., 1999b. The role of earthworms for assessment of sustainability and as bioindicators. In: Paoletti, M.G. (Ed.), Invertebrate Biodiversity as Bioindicators of Sustainable Landscapes. Agric. Ecosyst. Environ. 74, 137-155.

Paoletti, M.G., Hassal, M., 1999. Woodlice (Isopoda: Oniscoidea): their potential for assessing sustainability and use as bioindicators. In: Paoletti, M.G. (Ed.), Invertebrate Biodiversity as Bioindicators of Sustainable Landscapes. Agric. Ecosyst. Environ. 74, 157-165.

Paoletti, M.G., Iovane, E., Cortese, M., 1988. Pedofauna bioindicators as heavy metals in five agro-ecosystems in north-east Italy. Rev. Ecol. Biol. Sol. 25 (1), 33-58.

Perner, J., 2003. Sample size and quality of bioindication: a case study using ground-dwelling arthropods in agricultural ecosystems. In: Büchs, W. (Ed.), Biotic Indicators for Biodiversity and Sustainable Agriculture. Agric. Ecosyst. Environ. 98, 125-132.

Perner, J., Malt, S., 2003. Assessment of changing agricultural land use: response of vegetation, ground-dwelling spiders and beetles to the conservation of arable land into grassland. In: Büchs, W. (Ed.), Biotic Indicators for Biodiversity and Sustainable Agriculture. Agric. Ecosyst. Environ. 98, 169-181.

Pfiffner, L., 1997. Welchen Beitrag leistet der ökologische Landbau zur Förderung der Kleintierfauna. In: Weiger, H., Willer, H. (Eds.), Naturschutz durch ökologischen Landbau. Bad Dürkheim, Holm, Germany, pp. 93-120. 
Pfiffner, L., Luka, H., 1996. Laufkäfer-Förderung durch Ausgleichsflächen. Auswirkungen neu angelegter Grünstreifen und einer Hecke im Ackerland. Naturschutz und Landschaftsplanung 28, 145-151.

Pfiffner, L., Luka, H., 1999. Faunistische Erfolgskontrolle von unterschiedlichen Anbausystemen und naturnahen Flächen im Feldbau-Bedeutung des ökologischen Landbaues. In: Büchs, W. (Ed.), Nicht bewirtschaftete Areale in der Agrarlandschaft-ihre Funktionen und ihre Interaktionen mit landnutzungsorientierten Ökosystemen. Mitteilungen aus der Biologischen Bundesanstalt für Land- und Forstwirtschaft 368, 57-67.

Pfiffner, L., Mäder, P., 1997. Effects of biodynamic, organic and conventional production systems on earthworm populations. Biol. Agric. Horticult. 15, 3-10.

Pfiffner, L., Niggli, U., 1996. Effects of biodynamic, organic and conventional farming on ground beetles (Col., Carabidae) and other epigaeic arthropods in winter wheat. Biol. Agric. Horticult. 12, 353-364.

Pfiffner, L., Luka, H., Jeanneret, P., Schüpbach, B., 2000. Effekte ökologischer Ausgleichsflächen auf die Laufkäferfauna. Agrarforschung 7 (5), 212-217.

Piorr, H.-P., 2003. Environmental policy, agri-environmental indicators and landscape indicators. In: Büchs, W. (Ed.), Biotic Indicators for Biodiversity and Sustainable Agriculture. Agric. Ecosyst. Environ. 98, 17-33.

Platen, R., Moritz, M., von Broen, B., 1991. Liste der Webspinnenund Weberknechtarten (Arach.: Araneida, Opilionida) des Berliner Raumes und ihre Auswertung für Naturschutzzwecke (Rote Liste). In: Platen, R., Sukopp, H. (Eds.), Rote Listen der gefährdeten Pflanzen und Tiere in Berlin, Landschaftsentwicklung und Umweltforschung 6, 169-205.

Poehling, H.M., Vidal, S., Ulber, B., 1994. Genug Nützlinge auf Großflächen-Wunsch oder Wirklichkeit? Pflanzenschutz-Praxis 3, 34-38.

Popov, V.V., Krusteva, I.A., 2000. Epigeobiont animal assemblages from two landscapes of the Bulgarian black sea cost: relationship to environmental gradients, assemblage structure and biodiversity. I. Ground beetles (Coleoptera: Carabidae). Acta Zool. Bulgarica 51, 81-114.

Potts, G.R., 1986. The Partridge: Pesticides, Predation and Conservation. Collins Publisher.

Prescher, S., Büchs, W., 1997. Zum Einfluß abgestufter Extensivierungsmaßnahmen und selbstbegrünender Dauerbrache auf funktionelle Gruppen der Brachycera (Diptera). Verhandlungen der Gesellschaft für Ökologie 27, 385-391.

Prescher, S., Büchs, W., 2000. Der Einfluß abgestufter Extensivierungsmaßnahmen im Ackerbau auf die Struktur der phytophagen Brachycerazönose. Mitteilungen der Deutschen Gesellschaft für allgemeine und angewandte Entomologie 12, 347-352.

Prestidge, R.A., 1982. The influence of nitrogenous fertilizer on the grassland Auchenorrhyncha. J. Appl. Ecol. 19, 735-749.

Radford, B.J., Key, A.J., Robertson, L.N., Thomas, G.A., 1995. Conservation tillage increases soil water storage, soil animal population, grain yield and response to fertiliser in the semi-arid tropics. Aust. J. Exp. Agric. 35, 223-232.
Rahmel, U., Ruf, A., 1994. Eine Feldmethode zum Nachweis von anthropogenem Stress auf natürliche Tierpopulationen: "Fluctuating asymmetry". Natur und Landschaft 69, 104-107.

Raskin, R., Glück, E., Pflug, W., 1992. Floren- und Faunenentwicklung auf herbizidfrei gehaltenen Ackerflächen. Natur und Landschaft 67, 7-14.

Rehfeldt, G.-E., 1984. Bewertung ostniedersächsischer Flussauen durch Bioindikatorsysteme-Modell einer Landschaftsbewertung. Ph.D. thesis, Faculty of Natural Sciences, Technical University of Braunschweig, Braunschweig, Germany, $259 \mathrm{pp}$.

Remmert, H., 1984. Ökologie, third ed. Springer Verlag, Berlin, 334 pp.

Retnakaran, A., Smith, L., 1980. Web-spinning in spiders is unaffected by moult-inhibiting insect-growth regulator BAY SIR 8514. Bimonthly Res. Notes 36 (4), 19-20.

Rhee, J., 1997. Effects of soil pollution on earthworms. Pedobiologia 17, 201-208.

Richter, J., Bachinger, J., Stachow, U., 1999. Einfluss der Standortheterogenität innerhalb von Großschlägen auf die Segetalflora unter organischer und konventioneller Bewirtschaftung in Ostbrandenburg. Beiträge zur 5 . Wissenschaftstagung zum Ökologischen Landbau "Vom Rand zur Mitte", pp. 416-419.

Riechert, S.E., Harp, J.M., 1987. Nutritional ecology of spiders. In: Slansky, F., Rodriguez, J.G. (Eds.), Nutritional Ecology of Insects, Mites and Spiders, pp. 645-672.

Riechert, S.E., Tracy, C.R., 1975. Thermal balance and prey availability: the basis for a model relating web site characteristics to spider reproductive success. Ecology 56 (2), 265-284.

Riecken, U., 1992. Planungsbezogene Bioindikation durch Tierarten und Tiergruppen. Grundlagen und Anwendung. Schriftenreihe für Landschaftspflege und Naturschutz 36, 1-187 (Münster: Landwirtschaftsverlag, Germany).

Riecken, U., 1997. Arthropoden als Bioindikatoren in der naturschutzrelevanten Planung-Anwendung und Perspektive. Mitteilungen der Deutschen Gesellschaft für allgemeine und angwandte Entomologie 11, 45-56.

Rösler, S., Weins, C., 1997. Situation der Vogelwelt in der Agrarlandschaft und der Einfluß des ökologischen Landbaus auf ihre Bestände. In: Weiger, H., Willer, H. (Eds.), Naturschutz durch ökologischen Landbau. Bad Dürkheim, Holm, Germany, pp. 121-152.

Roth, D., Schwabe, M., 2003. Method for assessing the proportion of ecologically, culturally and provincially significant areas ("OELF") in agrarian spaces used as a criterion of environmentally friendly agriculture. In: Büchs, W. (Ed.), Biotic Indicators for Biodiversity and Sustainable Agriculture. Agric. Ecosyst. Environ. 98, 435-441.

Roush, R.S., Radabough, D.C., 1993. Web density is related to prey abundance in cellar spiders, Pholcus phalangoides (Füsslin) (Araneae, Pholcidae). Bull. Br. Arachnol. Soc. 9 (5), 142-144.

Ruf, A., 1998. A maturity index for predatory soil mites (Mesostigmata: Gamasina) as an indicator of environmental impacts of pollution on forest soil. Appl. Soil Ecol. 6, 447-452.

Ruzicka, V., Bohac, J., 1994. The utilization of epigaeic invertebrate communities as bioindicators of terrestrial 
environmental quality. In: Salanki, J., Jeffrey, D., Hughes, G.M. (Eds.), Biological Monitoring of the Environment: A Manual of Methods. CAB International, Wallingford, pp. 79-86.

Sampels, J., 1986. Die Käfer der Weinbergsvegetationsschicht und ihre Eignung als Indikatoren der Standortbelastung. Ph.D. thesis, University of Bonn, Germany, 224 pp.

Saxena, K.G., Rao, K.S., Ramakrishnan, P.S., 1999. Ecological context of biodiversity. In: Shantharam, S., Montgomery, J.F. (Eds.), Biotechnology, Biosafety and Biodiversity: Scientific and Ethical Issues for Sustainable Developments. Science, Enfield, USA, pp. 129-156.

Scheu, S., 1999. Biologische Vielfalt und Ökosystemfunktion. In: Hummel, M.E., Simon, H.-R., Scheffran, J. (Eds.), Konfliktfeld Biodiversität: Erhalt der biologischen Vielfalt-Interdisziplinäre Problemstellungen. Working Paper IANUS 7 (1999), 3-13.

Scheu, S., 2001. Plants and generalist predators as mediators between the below-ground and the above-ground system. Basic Appl. Ecol. 2, 3-13.

Schloter, M., Bach, H.-.J., Metz, S., Sehy, U., Munch, J.C., 2003. Influence of precision farming on the microbial community structure and functions in nitrogen turnover. In: Büchs, W. (Ed.), Biotic Indicators for Biodiversity and Sustainable Agriculture. Agric. Ecosyst. Environ. 98, 295-304.

Schröter, L., Irmler, U., 1999. Einfluß von Bodenart, Kulturfrucht und Feldgröße auf Carabiden-Synusien der Äcker des konventionell-intensiven und des ökologischen Landbaus. Faunistisch-Ökologische Mitteilungen Supplement 27, 1-61.

Schubert, R., 1984. Lehrbuch der Ökologie. Gustav Fischer Verlag, Jena, 595 pp.

Sedlacek, J.D., Barrett, G.W., Shaw, D.R., 1988. Effects of nutrient enrichment on the Auchenorrhyncha (Homoptera) in contrasting grassland communities. J. Appl. Ecol. 25, 537-550.

Shannon, C.E., 1948. A mathematical theory of communication. Bull. Syst. Technol. J. 27, 379-423, 623-656.

Shannon, C.E., Weaver, W., 1963. The Mathematical Theory of Communication. University of Illinois Press, Urbana, $117 \mathrm{pp}$.

Siepel, H., 1994. Life-history tactics of soil microarthropods. Biol. Fertil. Soils 18, 263-278.

Siepel, H., 1995. Applications of microarthropod life-history tactics in nature management and ecotoxicology. Biol. Fertil. Soils 19, 75-83.

Siepel, H., 1996. The importance of unpredictable and short-term environmental extremes for biodiversity in oribatid mites. Biodivers. Lett. 3, 26-34.

Sommaggio, D., 1999. Syrphidae: can they be used as environmental bioindicators? In: Paoletti, M.G. (Ed.), Invertebrate Biodiversity as Bioindicators of Sustainable Landscapes. Agric. Ecosyst. Environ. 74, 343-356.

Speight, M.C.D., McLEan, L.F.G., Goeldlin de Tiefenau, P., 1992. The recognition of sites of international importance for protection of invertebrates. Environ. Encounters Ser. 14, 39-42.

Ssymank, A., 1993. Zur Bewertung und Bedeutung naturnaher Landschaftselemente in der Agrarlandschaft. Teil I. Schwebfliegen (Diptera: Syrphidae). Verhandlungen der Gesellschaft für Ökologie 22, 255-262.

Stachow, U., Büchs, W., Schultz, A., Lutze, G., Latus, C., 2001. Assessment and evaluation of biodiversity in agricultural landscapes. In: Zotz, G., Körner, C. (Eds.), Functional Importance of Biodiversity. Verhandlungen der Gesellschaft für Ökologie, 2001. Parey-Verlag, Berlin, Germany, 31 pp.

Standing Committee on Agriculture and Resource Management, 1993. Sustainable agriculture - tracking the indicators for Australia and New Zealand. SCARM Report 51, BRS, Canberra, pp. 1-62.

Steenmans, C., Pingborg, U., 2001. Anthropogenic fragmentation potential semi-natural and natural areas. In: EU-Commission (Ed.), From Land Cover to Landscape Diversity in the European Union. Brussels, Belgium, 6 pp. (+3 maps).

Steidl, I., Ringler, A., 1997. Agrotope (Teilband)Landschaftspflegekonzept Bayern. In: Bayerisches Staatsministerium für Landesentwicklung und Umweltfragen, Bayerische Akademie für Naturschutz und Landschaftspflege, Vol. II. München, Germany, p. 11.

Steinborn, H.-A., Heydemann, B., 1990. Indikatoren und Kriterien zur Beurteilung der ökologischen Qualität von Agrarflächen am Beispiel der Carabidae (Laufkäfer). Schriftenreihe Landschaftspflege und Naturschutz 32, 165-174.

Steinborn, H.-A., Meyer, H., 1994. Einfluß alternativer und konventioneller Landwirtschaft auf die Prädatorenfauna in Agrarökosystemen Schleswig-Holsteins (Araneida, Coleoptera: Carabidae, Diptera: Dolichopodidae, Empididae, Hybotidae, Microphoridae). Faunistisch-Ökologische Mitteilungen 6, 409438.

Steiner, N.C., Köhler, W., 2003. Effects of landscape patterns on species richness - a modelling approach. In: Büchs, W. (Ed.), Biotic Indicators for Biodiversity and Sustainable Agriculture. Agric. Ecosyst. Environ. 98, 353-361.

Steinmann, H.-H., Gerowitt, B., 2000. Ackerbau in der Kulturlandschaft-Funktionen und Leistungen. Ergebnisse des Göttinger INTEX-Projektes. Mecke Verlag, Duderstadt, Germany, $300 \mathrm{pp}$.

Stern, K., Tigerstedt, P.M.A., 1974. Ökologische Genetik. Fischer Verlag, Stuttgart.

Stippich, G., Krooß, S., 1997. Auswirkungen von Extensivierungsmaßnahmen auf Spinnen, Laufkäfer und Kurzflügelkäfer. In: Gerowitt, B., Wildenhayn, M. (Eds.), Ökologische und ökonomische Auswirkungen von Extensiverungsmaßnahmen im Ackerbau-Ergebnisse des Göttinger INTEX-Projektes 1990-1994, pp. 221-262.

Stork, N.E., 1995. Measuring and monitoring arthropod diversity in temperate and tropical forests. In: Boyle, T.J.B., Boontawee, B. (Eds.), Measuring and Monitoring Biodiversity in Temperate and Tropical Forests. CIFOR, Bogor, pp. 257-270.

Stork, N.E., Eggleton, P., 1992. Invertebrates as determinants and indicators of soil quality. Am. J. Alternative Agric. 7, 38-47.

Stugren, B., 1978. Grundlagen der allgmeinen Ökologie. Stuttgart, New York.

Tembrock, G., 1982/1983. Spezielle Verhaltensbiologie der Tiere. Gustav Fischer Verlag, Jena, 1040 pp.

Tilman, D., Knops, J., Wedlin, D., Reich, P., Ritchie, M., Siemann, E., 1997. The influence of functional diversity and composition on ecosystem processes. Science 277, 1300-1302.

The Soil Association (Ed.), 2000. The Biodiversity Benefits of Organic Farming. Bristol, UK, 34 pp. 
Topp, W., 1989. Laufkäfer als Bioindikatoren in der Kulturlandschaft. Verhandlungen 9. SIEEC Gotha 1986, pp. $78-82$.

Tscharntke, T., Gathmann, A., Steffan-Dewenter, I., 1998. Bioindication using trap-nesting bees and wasps and their natural enemies: community structure and interactions. J. Appl. Ecol. 35 (5), 708-719.

Usseglio-Polatera, P., Bornaud, M., Richoux, P., Tachet, H., 2000. Biomonitoring through biological traits of benthic macroinvertebrates: how to use species trait databases? In: Jungwirth, M., Muhar, S., Schmutz, S. (Eds.), Assessing the Ecological Integrity of Running Waters. Hydrobiologia 422-423, 153-162.

Van Dijk, T., 1986. On the relationship between availability of food and fecundity in carabid beetles. How far is the number of eggs in the ovaries a measure of the quantities of food in the field. Report of the Fifth European Symposium on Carabidae, pp. 105-120.

Van Elsen, T., 1996. Wirkungen des ökologischen Landbaues auf die Segetalflora-Ein Übersichtsbeitrag. In: Deipenbrock, W., Hülsbergen, K.-J. (Eds.), Langzeiteffekte des ökologischen Landbaus auf Fauna, Flora und Boden. Halle/Saale, Germany, pp. 143-152.

Van Elsen, T., 2000. Organic Farming as a challenge for the integration of agriculture and nature development. In: Stolton, S., Geier, B., McNeely, J.A. (Eds.), The Relationship between Nature Conservation, Biodiversity and Organic Agriculture. Proceedings of the International Workshop, Vignola, Italy, 1999, pp. 76-85.

Van Vliet, P.C.J., Beare, M.H., Coleman, D.C., 1995. Population dynamics and functional role of Enchytraeidae (Oligochaeta) in hardwood forests and agricultural ecosystems. Plant Soil 170 (1), 199-207.

Vermeulen, A.C., 1995. Elaborating chironomid deformities as bioindicators of toxic sediment stress: the potential application of mixture toxicity concepts. Ann. Zool. Fennici 32, 265-285.

Von Euler, F., 1999. An objective indicator of functional integrity in avian communities. In: Gustafsson, L., Weslien, J.O. (Eds.), Biodiversity in Managed Forests-Concepts and Solutions. For. Ecol. Manage. 115, 221-229.

Volkmar, C., Wetzel, T., 1998. Zum Auftreten gefährdeter Spinnen (Arachnida: Araneae) auf Agrarflächen in Mitteldeutschland. Archiv für Phytopathologie und Pflanzenschutz 31, 561-574.

Volkmar, C., Bothe, S., Kreuter, T., Lübke-Al Hussein, M., Richter, L., Heimbach, U., Wetzel, T., 1994. Epigäische Raubarthropoden in Winterweizenbeständen Mitteldeutschlands und ihre Beziehung zu Blattläusen. Mitteilungen aus der Biologischen Bundesanstalt für Land- und Forstwirtschaft Berlin Dahlem, Heft 299, 134.

Vollrath, F., 1988. Spider growth as an indicator of habitat quality. Bull. Br. Arachnol. Soc. 7 (7), 217-219.

Waldhardt, R., 2003. Biodiversity and landscape-summary, conclusions and perspectives. In: Büchs, W. (Ed.), Biotic Indicators for Biodiversity and Sustainable Agriculture. Agric. Ecosyst. Environ. 98, 305-309.

Waldhardt, R., Otte, A., 2000. Zur Terminologie und wissenschaftlichen Anwendung des Begriffs Biodiversität. Wasser Boden 52 (1-2), 10-13.
Waldhardt, R., Otte, A., 2003. Indicators of plant species and community diversity in grasslands. In: Büchs, W. (Ed.), Biotic Indicators for Biodiversity and Sustainable Agriculture. Agric. Ecosyst. Environ. 98, 339-351.

Wallin, H., 1985. Spatial and temporal distribution of some abundant carabid beetles (Coleoptera: Carabidae) in cereal fields and adjacent habitats. Pedobiologia 28, 19-34.

Wallin, H., 1989. The influence of different age classes on the seasonal activity and reproduction of four medium-sized carabid species inhabiting cereal fields. Holarctic Ecol. 12, 201-212.

Wang, D., Lowery, B., McSweeney, K., 1996. Spatial and temporal patterns of ant burrow openings as affected by soil properties and agricultural practices. Pedobiologia 40, 201-211.

Warwick, W.F., 1988. Morphological deformities in Chironomidae (Diptera) larvae as biological indicators of toxic stress. In: Evans, M.S. (Ed.), Toxic Contaminants and Ecosystem Health: A Great Lakes Focus. Wiley, New York, pp. 280-310.

Warwick, R.M., Clarke, K.R., 1998. Taxonomic distinctness and environmental assessment. J. Appl. Ecol. 35 (4), 532-543.

Watt, A.D., Stork, N.E., Eggleton, P., Srivastava, D.S., Bolton, B., Larsen, T.B., Brendell, M.J.D., Bignell, D.E., 1997. Impact of forest loss and regeneration on insect abundance and diversity. In: Watt, A.D., Hunter, M., Stork, N.E. (Eds.), Forests and Insects. Chapman \& Hall, London, pp. 273-286.

Weber, G., Franzen, J, Büchs, W., 1997. Beneficial Diptera in field crops with different input of pesticides and fertilizers. In: Kromp, B., Meindl, P. (Eds.), Entomological Research in Organic Farming. Biol. Agric. Horticult. 15, 109-122.

Weigmann, G., Jung, E., 1992. Die Hornmilben (Acari, Oribatida) au Straßenbäumen in Stadtzonen unterschiedlicher Luftbelastung in Berlin. Zool. Beitr. 34, 273-287.

Weiss, E., Nentwig, W., 1992. The importance of flowering plants on sown weed strips for beneficial insects in cereal fields. Mitteilungen der Deutschen Gesellschaft für allgemeine und angewandte Entomologie 8, 133-136.

Wetzel, T., 1993. Genug Nützlinge auch auf Großflächen. Pflanzenschutz-Praxis 4, 16-19.

Wetzel, T., Volkmar, C., Lübke-Al Hussein, M., Jany, D., Richter, L., 1997. Zahlreiche "Rote-Liste-Arten" epigäischer Raubarthropoden auf grossen Agrarflächen Mitteldeutschlands. Archiv für Phytopathologie und Pflanzenschutz 31, 165-183.

Wheater, C.P., Cullen, W.R., Bell, J.R., 2000. Spider communities as tools in monitoring reclaimed limestone quarry landforms. Landsc. Ecol. 15, 401-406.

Wicke, G., 1998. Stand der Ackerrandstreifenprogramme in Deutschland. Schriftenreihe der Landesanstalt für Pflanzenbau und Pflanzenschutz 6, 55-84.

Wiener, N., 1948. Cybernetics. New York.

Willems, E., Vandevoort, C., Willekens, A., Buffaria, B., 2001. 3. Landscape and land cover diversity index. In: EU-Commission (Ed.), From Land Cover to Landscape Diversity in the European Union. Brussels, Belgium, 17 pp. (+1 table and 23 maps).

Wise, D.H., 1979. Effects of an experimental increase in prey abundance upon reproductive rates of two orb-weaving spider species (Araneae, Araneidae). Oecologia 41, 289-300.

Wittasek, R., 1987. Untersuchung zur Kupferanreicherung in der Bodenfauna eines Weinbergökosystems. In: Welz, B. (Ed.), Colloquium Atomspektrometrische Spurenanalytik, Überlingen. 
World Bank (Ed.), 1998. Guidelines for Monitoring and Evaluation for Biodiversity Projects: Environment. Department Papers, Biodiversity Series No. 065.

Yeates, G.W., Bongers, T., 1999. Nematode diversity in agro-ecosystems. In: Paoletti, M.G. (Ed.), Invertebrate Biodiversity as Bioindicators of Sustainable Landscapes. Agric. Ecosyst. Environ. 74, 113-135.

Zanger, A., Lys, J.-A., Nentwig, W., 1994. Increasing the availability of food and the reproduction of Poecilus cupreus in a cereal field by strip management. Entomologia Experimentalis et Applicata 71, 111-120.
Zimmermann, J., Büchs, W., 1996, Management of arable crops and its effects on rove-beetles (Coleoptera: Staphylinidae) with special reference to the effects of insecticide treatments. In: Booj, C.J.H., den Nijs, L.J.M.F. (Eds.), Arthropod Natural Enemies in Arable Land. II. Survival, Reproduction and Enhancement. Acta Jutlandica 71 (2), 183-194.

Zimmermann, J., Büchs, W., 1999. Kurzflügelkäfer (Coleoptera: Staphylinidae) in unterschiedlich intensiv bewirtschafteten Ackerflächen. Agrarökologie 32, 1-154. 